\title{
MODELING KOREAN UNIFICATION
}

\author{
Marcus Noland \\ Institute of International Economics
}

Sherman Robinson

International Food Policy Research Institute

\author{
Tao Wang \\ Institute of International Economics
}

July 1999

\begin{abstract}
For North Korea, product market integration would generate large welfare gains, sufficient to end the famine. Additional gains could be had through military demobilization. For the South, the impact of product market integration would be trivial, but the impact of factor market integration would be considerable, affecting the composition of output, distribution of income, and rate of growth.

Given moderately rapid technological convergence, expected levels of cross-border migration, and equalization of rates on return on capital, per capita incomes in the North would remain well below those in the South for an extended period.
\end{abstract}

Correspondence address: Marcus Noland, Institute for International Economics, 11 Dupont Cir., NW Washington, DC 20036 USA; 202-328-9000; 202-329-5432 (fax); mnoland@iie.com. We would like to thank seminar participants at the World Bank for helpful comments on an earlier draft. Mina Kim provided helpful research assistance. 


\section{TABLE OF CONTENTS}

INTRODUCTION $\ldots \ldots \ldots \ldots \ldots \ldots \ldots \ldots \ldots \ldots \ldots \ldots \ldots \ldots \ldots$

THE KOREAN INTEGRATION MODEL $($ KIM) $\ldots \ldots \ldots \ldots \ldots \ldots \ldots \ldots \ldots$

Modeling Quantity Controls in Trade ........................ 7

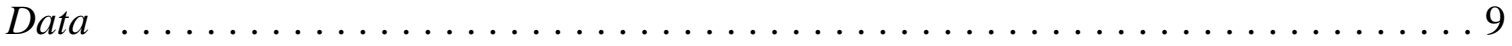

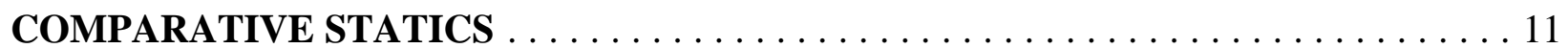

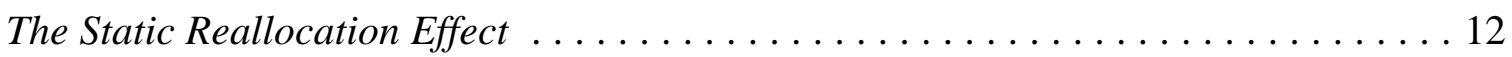

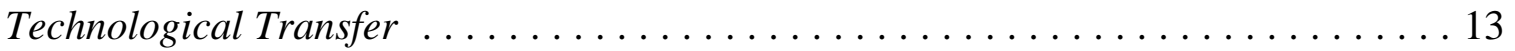

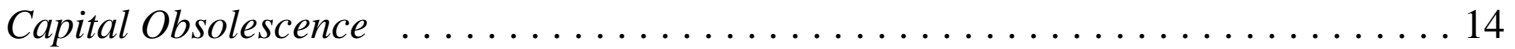

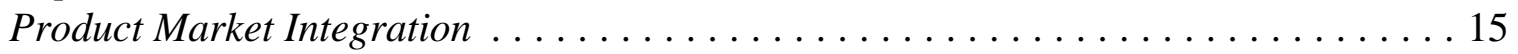

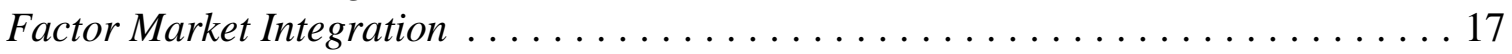

Foreign Capital Inflow . . . . . . . . . . . . . . . . . . . . . . . . 19

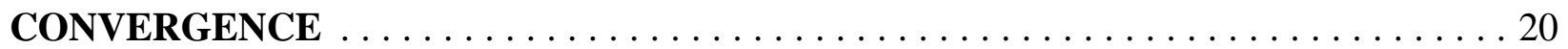

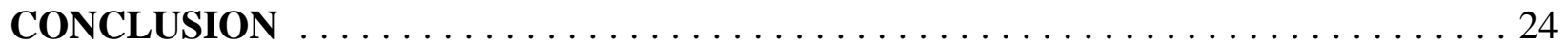

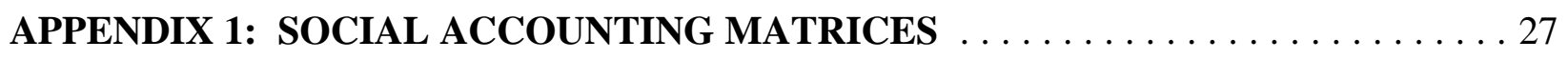

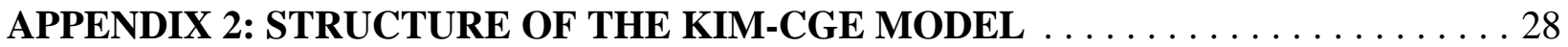

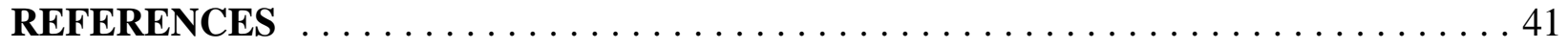




\section{INTRODUCTION}

The North Korean economy has been in decline for the better part of a decade. Under duress, the current regime has undertaken some modest reforms, but these have not fundamentally altered the centrally planned character of the economy and are unlikely to reverse the economy's downward spiral. ${ }^{1}$ In one poll of scholars, 38 percent of the respondents predicted that the current regime would not last a decade (Y.S. Lee, 1995). In a more recent poll, the respondents' mean subjective probability of collapse was 26 percent, while the mean estimate of significant reform was 40 percent (Noland, 1998, Table 1).

One obvious direction of reform would be marketization of the economy and openess to greater interaction with the outside world - including South Korea. Greater North-South economic integration, either in the context of a reform strategy initiated by the North or in the context of collapse and absorption by the South, potentially could have profound effects on both economies, yet scant effort has been devoted to constructing economic models to analyze this possibility. In this paper, we start from incomplete data ridden with gross measurement errors and, using cross-entropy estimation techniques, construct the underlying data base for a computable general equilibrium model (CGE) of Korean economic integration. This estimation approach is powerful and flexible, allowing us to make full use of what information we have in whatever form. CGE modeling forces internal consistency. The end product, the Korean Integration Model (KIM), is a two-country CGE model linking the North and South Korean economies. The model incorporates fragmentary information in a rigorous way and allows us to examine the implications of a number of alternative integration scenarios, extending previous studies of integration by Noland, Robinson, and Liu ((NRL) 1998, 1998) which used an earlier version of KIM. The new KIM is an updated version of the earlier model described in NRL (1999).

The NRL studies developed an eight-sector, four-factor, constant-returns-to-scale CGE model of the North and South Korean economies calibrated to 1990, the most recent year before North Korea entered a period of severe macroeconomic instability. These studies concluded that the extent of cross-border factor mobility was key. If the two countries formed a customs union,

\footnotetext{
${ }^{1}$ See Noland (1996) for an overview of the North Korean economy and additional references not cited in this paper.
} 
freeing cross-border trade in goods, but not in factors, the macroeconomic impact on South Korea would be slight. In contrast, the impact of economic integration with the North on the South Korean economy would be non-trivial once restrictions on cross-border labor and mobility were removed. In particular, there would be a shift in the South Korean distribution of income toward capital, and within labor toward urban high-skill labor, suggesting increased income and wealth inequality in the South once capital began flowing North and labor began flowing South. However, under one scenario, the present discounted value of the South Korean income stream under integration actually exceeded the baseline no integration figure, indicating that the South Korean economy as a whole could be better off with integration and also indicating that, with proper redistribution, economic integration of the Korean peninsula could be Pareto-improvingeveryone would be better off.

This result crucially depended on two modeling assumptions, however. First, the form of capital transer from the South to the North had to take the form of profit-making investment which yielded a stream of remitted profits to Southern investors. If the transfers were modeled as grants, capital earnings would remain in the North, and the possibility of economic integration that would benefit the South relative to a no integration baseline would disappear.

The result also depended critically on the rapidity of technological convergence between the North and the South. In the potentially Pareto-improving case, the North adopts South Korean technology over the a decade, attaining not only Southern levels of total factor productivity (TFP), but the Southern input mix as well. ${ }^{2}$

In this paper, we extend that earlier work in two principal ways. First, conditions on the Korean peninsula have changed considerably since 1990 (the date of calibration of the earlier models), most obviously with the emergence of a famine in North Korea. Economic distress has forced North Korea into greater openness, and as a consequence, more information about the North Korean economy has become available. The United Nations Development Programme (UNDP) has been working with the government of North Korea to construct standard national accounts, and some of these data were released to an IMF mission that visited North Korea in

\footnotetext{
${ }^{2}$ It appears that North Korea wastes a lot of intermediate inputs, as is typical of centrally planned economies (CPEs).
} 
1997 (IMF, 1997). Other international bodies such as the Food and Agricultural Organisation (FAO) and the World Food Programme (WFP) have released data associated with their famine relief work. This newly available information has made it possible to extend and recalibrate the earlier North Korea model to 1996, reflecting North Korea's changed circumstances. In particular, it is now possible to examine the impact of economic integration on the North Korean famine. It is also plausible that the process of economic integration could be accompanied by political rapprochement or unification. We consequently examine the potential for a "peace dividend" associated with military demobilization.

These issues can be usefully examined in a comparative static framework. Some issues are inherently dynamic, however. Cross-border investment and technological change will not occur instantly, so the speed of technological convergence is a critical issue. Barro and Sala-i-Martin $(1992,1995)$ present evidence that countries with low initial levels of per capita income tend to exhibit higher per capita income growth than countries with initially higher per capita income levels. That is to say, there is a tendency toward per capita income convergence. Indeed, Barro and Sala-i-Martin argue that in a variety of contexts (among US states, among members of the $\mathrm{OECD}$, among all countries) there is a tendency for poorer regions to converge on the incomes of richer regions, conditional on other factors, at a rate of roughly two percent annually.

Yet this "two percent rule" is probably inadequate for the task at hand. Rather than convergence in the steady state growth paths of regions with at least access to similar production technology, the economic integration of North and South Korea would arguably put North Korea on a new growth path, at least transitionally. Evidence from the German case suggests that the speed of technological convergence between East and West Germany has been considerably higher than two percent annually. Thus in the second part of the paper, we combine the analysis of cross-border factor flows with the literature on intra-German technological convergence to examine the implications of realistic estimates of the speed of technological upgrading for income convergence, the "costs of unification," and the incentives for cross-border labor migration.

Having raised the comparison with the German case, it is worthwhile to indicate at the outset some issues that this paper does not address. Given our model's medium-to-long-run orientation, the focus is primarily on sectoral adjustment issues in the context of a simple 
macroeconomic framework. For two principal reasons we do not address a number of interesting macroeconomic issues, such as exchange rate overshooting, which have been prominent in the literature on German unification. ${ }^{3}$ First, the disimilarity of factor endowments is far more pronounced in the Korean case than in the German case (Noland, 1997). As a consequence, integration may have more dramatic sectoral implications in the Korean case compared to the German case. This fact, combined with the far larger differences in economic size between the two Koreas compared to pre-unification Germany, suggests that in certain respects the North American Free Trade Agreement (NAFTA) may be a closer analogue to the prospective Korean situation than the German experience. The KIM is well-suited for examining these integration issues.

Second, history does not operate by analogy. There is no particular reason to believe that adjustment issues that arose in the German case, and which were at least partly due to avoidable policy mistakes (such as the wage equalization policy), would occur in the Korean case. Indeed, the Koreans can learn from the German experience and avoid some of the German errors. ${ }^{4}$ To cite a specific example, in contrast to the German wage equalization policy, most Korean analysts expect the maintenance of the existing demilitarized zone to control population movements after economic integration and also expect the perpetuation of greatly differing wage structures in the two halves of the peninsula for some extended period of time (cf. Young, Lee, and Zang, 1998).

Finally, we should observe that in this paper we simply model a customs union and exchange rate unification; these do not require political unification, just economic integration, and on the political issue our paper is agnostic. ${ }^{5}$

\footnotetext{
${ }^{3}$ There is now a sizable literature on German unification. See Lipschitz and McDonald (1990), Akerlof et al (1991), Sinn and Sinn (1992), Dornbusch and Wolf (1994), Carlin and Meyer (1994), Thimann and Breitner (1995), Hughes Hallett, Ma, and Melitz (1996), Dyck (1997) among others.

${ }^{4}$ See Yeon (1994), Flassbeck and Horn (1996), Noland (1997), and Wolf (1998) for analyses of the lessons for Korea from the German experience.

${ }^{5}$ Another possible scenario is monetary union between North and South Korea. In a real model such as the KIM, with no money or financial markets, monetary union simply implies a unified (or fixed) exchange rate between the two countries and a unified trade balance as well.
} 


\section{THE KOREAN INTEGRATION MODEL (KIM)}

The KIM is a member of a growing family of trade-focused, multi-country, CGE models designed to analyze the impact of trade liberalization and the formation of free trade areas and customs unions. The KIM consists of two linked country CGE models, one for North Korea and one for South Korea. The rest of the world is included by means of a simple representation of fixed world prices for North and South Korean exports and imports. The countries are linked by trade flows, and the model solves for all internal prices, including commodity and factor prices, and external prices of all goods traded between the two countries. Domestically produced and traded goods are specified as imperfect substitutes, providing for a realistic continuum of "tradability" and allowing two-way intersectoral trade.

The KIM has a standard neoclassical specification, except that the model incorporates severe quantity controls on exports and imports with concomitant distortions in domestic product and factor markets. The markets for goods, factors, and foreign exchange are assumed to respond to changing demand and supply conditions, which, in turn, are affected by government policies, the external environment, and other exogenous influences. The model can be considered medium-to-long run in that all factors are assumed to be intersectorally mobile. It is Walrasian in that only relative prices matter. Sectoral product prices, factor prices, and the exchange rate are determined relative to an aggregate consumer price index, which defines the numeraire. ${ }^{6}$ The KIM has eleven sectors: rice, other grains, other agriculture/forest/fisheries, mining, light manufacturing, industrial intermediates, capital goods, construction, public administration, the military, and services. There are three "demanders": a single aggregate household which buys consumer goods, a government which spends on goods and public administration, and an aggregate capital account which purchases investment goods. The government is the sole, and completely price inelastic, demander of military services. All goods and services are traded internationally with the exceptions of construction, public administration, and the military.

Primary factors of production are land, capital, agricultural labor, high-skill urban labor,

\footnotetext{
${ }^{6}$ The exchange rate variable in the model can be seen as a price level deflated (PLD) real exchange rate, deflating by the numeraire cost of living index. Given that world prices are also assumed to be fixed, it is also equivalent to the "real effective exchange rate" (Williamson, 1994).
} 
and low-skill urban labor. Aggregate production functions were estimated for aggregate capital and labor using data reported in Hwang (1993) and Y.S. Lee (1994). The results are remarkably robust and plausible given the quality of the underlying data. Constant elasticity of substitution (CES) specifications yielded estimates of the aggregate substitutability between capital and labor of around unity. In most specifications, North Korea exhibited slightly negative TFP growth, which is typical of many pre-reform socialist economies. In the CGE model, sectoral production technology is represented by a set of CES functions of the primary factors to account for lower elasticities of substitution in sectors such as agriculture, mining, and the military. Intermediate inputs are demanded according to Leontief, fixed input-output coefficients. Labor and capital are intersectorally mobile; land is specific to agriculture, but mobile among the three agricultural sectors. ${ }^{7}$ Migration is permitted between rural and urban low-skill labor markets. On the demand side, import demand functions are specified as CES.

The KIM focuses on real trade flows, relative prices, and the real exchange rate. The aggregate price level in each country is taken as exogenous, and the model does not include money or other assets. The model includes the basic macro aggregates for each country, including the government deficit, the balance of trade, and the savings-investment balance. The balance of trade for each country is fixed exogenously (except when modeling full integration), so the model does not consider any possible macro feedbacks from trade liberalization to changes in international capital flows. The macro "closure" for each country is simple. Government revenue is determined endogenously, given a variety of fixed tax rates, while government expenditure is fixed exogenously. The government deficit is endogenous. Aggregate investment in each country is assumed to be a fixed share of total absorption (GDP plus imports minus exports), and aggregate savings is assumed to adjust to equate total savings and investment. ${ }^{8}$

\footnotetext{
${ }^{7}$ North Korean land is classified as high, medium, or low quality land following the FAO (1997) and the UNDP (1998). All South Korean land is classified as high quality. Rice is grown using high and medium quality land exclusively.

${ }^{8}$ While we fix external balances, we do not force the trade or current accounts to be balanced (i.e. we fix the trade balance of each country at its observed level in the base). Indeed, in a subsequent section of the paper, we subject the unified Korean trade balance to a set of external shocks to explore the real exchange rate implications of changes in the trade or current account balance.
} 
The KIM includes quantity rationing of both exports and imports. North Korea is assumed to have levels of "desired" exports and imports that would be typical for a country of its size and per capita income, but exports and imports are rationed physically, yielding the low levels observed in the base data. ${ }^{9}$ South Korean trade with North Korea is similarly assumed to be rationed in physical terms, and "desired" trade between the two countries is assumed to equal levels that would be predicted from a gravity model. Trade liberalization and integration in the form of a customs union is modeled by removing all quantity rationing and imposing a common external tariff equal to South Korean tariffs.

The KIM also includes a facility for modeling exchange rate unification by specifying: (1) a fixed exchange rate between North and South Korea, and (2) a unified, fixed, balance of trade for the two countries together. The result is that, in the various experiments done with this specification, the separate North and South Korean trade balances can vary, but their sum is fixed.

\section{Modeling Quantity Controls in Trade}

In the case of North Korea, the major distortion in the economy is assumed to be quantitative controls on both imports and exports. With respect to internal distortions, the largest single source of revenue is turnover taxes, which is typical in centrally planned economies (Noland, Robinson, and Wang 1999a, Table 3). These are allocated across the industrial sectors of the economy. ${ }^{10}$ Sectorally differentiated taxes and subsidies are treated straightfowardly in the case of South Korea. Demanders are assumed to treat imports and domestically produced goods as imperfect substitutes (the Armington assumption). They have a sectoral import demand

\footnotetext{
${ }^{9}$ The volume of "desired" trade is obtained through the use of a gravity model of international trade. The sectoral composition of that trade was estimated using detailed sectoral data on North Korean trade, together with the equivalent data from South Korea and Japan - North Korea's principal "natural" trading partners according to the gravity model. See Noland (1996) or Noland, Robinson, and Scatasta (1997) for details.

${ }^{10}$ These taxes present special problems for analysis because they are levied at differential rates depending on the legal status of the transacting parties. (For example, the tax wedge imposed on an exchange between two state enterprises is different than the wedge imposed on a transaction between a state enterprise and a cooperative.) Operationally, we assume that the turnover taxes are spread across the industrial sectors with a slight degree of escalation, as is often observed in CPEs. Implicitly we assume that North Korea is on, rather than inside, its production possibility frontier, though as argued below, our method of modeling technological transfer would put them on the frontier whether they were initially on it or not.
} 
function that depends on the relative prices of imports and domestically produced goods on the domestic market. These demand functions are parameterized according to the "normal" levels of sectoral imports that one would expect in North Korea without any rationing, given the results from the gravity model. Then, we assume the difference between desired imports and observed imports is due to the imposition of quantity rationing by the government. That is:

$$
\left(\frac{M_{i}}{D_{i}}\right)^{\text {rationed }}=\mathrm{qr}_{\mathrm{i}} \cdot\left(\frac{M_{i}}{D_{i}}\right)^{\text {desired }}
$$

where $M$ is imports, $D$ is domestic supply, $q r$ is the quantity rationing rate, and the subscript $i$ refers to the sector. ${ }^{11}$

The model also specifies sectoral export supply functions, where the export supply ratio depends on the ratio of the export price to the price on the domestic market. ${ }^{12}$ The supply functions are parameterized so that the desired ratio is consistent with the results from the gravity model. Symmetrically with the treatment of imports, quantity controls are specified so that actual exports are less than desired.

The result is that demanders are forced off their import demand curves, while producers are forced off their export supply curves. ${ }^{13}$ The distortions are quite large, indicating large potential gains from liberalizing trade and allowing markets to clear. Trade rationing leads to major distortions in the domestic price system as well. The equations of the model and further description are presented in Appendix 2.

\section{Data}

The model utilizes four main databases - macroeconomic and microeconomic Social Accounting Matrices (SAMs) of North and South Korea for 1996, the most recent year for which

\footnotetext{
${ }^{11}$ This approach to modeling import rationing was first used by Dervis, de Melo, and Robinson (1982), who discuss the properties of this approach, including questions of incentive compatibility.

${ }^{12}$ The sectoral export transformation functions are specified as constant elasticity of transformation (CET) functions.

${ }^{13}$ The degree of sectoral quantity rationing is given in Appendix Table 1.
} 
data is available. The SAM, described in Appendix 1, is a consistent array of economic transactions among agents that reconciles the input-output and national accounts. In the case of South Korea, the construction of the SAMs was straightforward. However in the case of North Korea, in estimating the SAM, we had to draw on a variety of sources, including incomplete national accounts, sectoral production and trade data, and estimates of government accounts. These data are not only incomplete, but also probably replete with serious measurement errors.

For the modeling exercise, we needed various share coefficients from the SAM, such as sectoral intermediate-input and value-added shares (for production functions) and expenditure shares (for consumption functions). Our problem was to estimate these coefficients, which required estimating a consistent SAM for the base-year of the model using scarce data measured with unknown error. Using standard econometric methods, the problem was essentially hopeless - there are not enough data to provide enough degrees of freedom to estimate the parameters, even if we were willing to make very strong assumptions about the error generation process -which we were not. However, in contrast to the usual situation in econometrics, we had a great deal of prior information about the parameters to be estimated. The structure of the SAM imposes powerful adding-up constraints, and we had information about the likely values of the various coefficients from a variety of sources, including comparative data from past periods and from other similar countries. The issue was how to use this information efficiently.

In this situation, we use an estimation approach, which Golan, Judge, and Miller (1996) call "maximum entropy econometrics", that draws on information theory. The estimation philosophy is to use all the information available, including information about the coefficients to be estimated, but not to assume any information that is unavailable. Our particular estimation approach applied to the SAMs is described in Golan, Judge, and Robinson (1994) and Robinson, Cattaneo, and El-Said (1998) and incorporates assumptions of estimation error (errors in variables) and prior knowledge about parts of the SAM (such as various macro aggregates). We incorporated prior information about the structure of the SAM by specifying an initial SAM which serves as a prior in the estimation, and reflected all the information we had (even if inconsistent). We then estimated a new SAM that is not only "close" to the old SAM - minimizing a "cross entropy" measure of the deviation between the two - but one that also: (1) satisfied all the 
adding-up constraints inherent in the definition of a SAM; (2) included any other constraints such as knowledge about parts of the SAM, (e.g., some of the national accounts or other aggregates); and (3) incorporated stochastic information about constraints involving measurement error. The method is both flexible and powerful in dealing with scattered and inconsistent data.

With respect to the macroeconomic SAM, we retained the assumption that the North Korean government makes all investments, but introduced a more elaborate revenue-generating system consistent with the North Korean data. However, since the North Korean data are internally inconsistent, the macro SAM does not balance. We estimated that the base GDP is roughly 32 billion won, higher than the officially reported 23 billion won. The reason is two-fold. First, the officially reported figure appears to exclude the military. Second, the officially reported data do not appear to be internally consistent when entered into a consistent SAM. Even assuming that little investment has occurred and that the capital stock has actually shrunk, the 1996 figures imply a tremendous decline in output relative to the 1990 SAM constructed by Noland, Robinson, and Scatasta. This result suggests that either there were very big reductions in factor supplies or that much of the economy was operating at ten to 15 percent of capacity. The simplest way to generate a consistent macro SAM was to assume higher output. While it may well be the case that floods, famine, and the practice of scrapping capital and bartering it for food have reduced factor supplies, and utilization of remaining capacity is low, there are also reasons to believe that the actual output is higher than reported by the authorities. ${ }^{14}$

With respect to the microeconomic SAM, the inter-industry relations from the Noland, Robinson, and Scatasta (1997) 1990 micro SAM for North Korea were used as a starting point (or prior), with some adjustments to reflect the apparent reduction in the capacity utilization rate (or, alternatively, decline in the value of the North Korean capital stock) and to obtain aggregate

\footnotetext{
${ }^{14}$ First, they have an incentive to understate output to increase international aid flows. Second, as mentioned in the text, the official data appear to refer only to output or resources controlled by the central planners. Evidence indicates that the military economy and economic activity outside the plan have increased, or at least have not decreased as rapidly as formal activity under the plan. Finally, aid flows, which account for a considerable share of food consumption, do not appear to be included in the official figures.
} 
consistency within the macro SAM. ${ }^{15}$

Urban workers were divided into high-skilled (professional, technical, and managerial) and low-skilled (the remainder). The initial starting point for industry employment structure was taken from pre-reform Chinese data. The wage premium was calculated on the basis of South Korean data. While one might expect a priori that wage dispersion in the North would be less than in the South, at this level of sectoral aggregation, the skilled wage premium obtained from the South Korean data was within the dispersion observed in fragmentary data on North Korean wages. The share of land in value-added was initially estimated from cross-country comparisons, yielding reasonable starting estimates of "rental rates" for different types of land.

\section{COMPARATIVE STATICS}

We studied integration under two main scenarios. The first scenario is the formation of a customs union which involves: (a) the elimination of North Korean quantity rationing of trade, (b) the elimination of intra-Korean barriers to trade, and c) the adoption of South Korea tariffs as the common external barrier. In this scenario, there is product, but not factor, market integration between North and South Korea. In this context, we also examined the possibility of a "peace dividend" obtainable through military demobilization. ${ }^{16}$

The second main scenario involves four variants on exchange rate unification, in which the real exchange rate is fixed between North and South Korea. In the first, capital moves from South to North Korea until North Korean per capita income rises to 60 percent that of the South's. In the second variant, this is achieved by allowing labor to migrate from North to South

15 The input-output coefficients contained in the 1990 prior SAM were in turn derived from a pre-reform (1979) Chinese input-output table compiled by the World Bank. This table was constructed using standard national accounts (SNA) conventions, expanding on the material product accounts (World Bank, 1985). The assumption is that a starting point (or prior) for the inter-industry input-output relations in North Korea is prereform China, reflecting their common links to 1970s vintage Soviet manufacturing technology. This prior was significantly altered in the estimation procedure.

${ }^{16}$ In the analysis that follows we interpreted income as a measure of welfare and ignored the role of security and the implications of economic change for military expenditure on the peninsula. It is possible for example that part of the welfare gains generated by economic integration could be lost if the two states used the gains to increase their military threat capabilities. If economic integration were accompanied by political integration, this issue would be moot. 
Korea. In the third variant, the per capita income target is achieved through the movement of both labor and capital. This formulation not only allows us to calculate the macroeconomic impacts of product and factor market integration, but also permits us to calculate income and its distribution with respect to the both the original populations of North and South Korea, and the post factor market integration distribution of population on the Korean peninsula. In the fourth variant, the source of capital inflow into North Korea is the rest of the world, not South Korea.

A final issue involves the specification of the production technology in North Korea. As argued in Noland, Robinson, and Scatasta (1997), and Noland, Robinson, and Wang (1999), liberalization of the North Korean economy is likely to involve at least three identifiable effects: static reallocation of factors according to comparative advantage; an increase in total factor productivity (TFP) associated with importation of capital equipment embodying new, superior, technology developed abroad; and an "obsolescence shock" reduction in the value of the existing capital stock.

\section{The Static Reallocation Effect}

As discussed above, the KIM model assumes that the base solution is highly distorted. Both exports and imports are severely quantity rationed, with producers and demanders assumed to be off their export supply and import demand functions. While we assume that factors are fully employed in the base, and therefore the economy is operating on its production possibility frontier, the composition of output and sectoral allocation of labor is incredibly distorted. When we perform counterfactual experiments in which we remove quantity rationing of imports and exports, the new free-trade equilibrium involves large changes in sectoral production - dramatic movement along the production possibility frontier — and large changes in relative prices compared to the initial rationed equilibrium.

Because the base prices are so distorted, even without considering any adjustment costs in the sense of unemployed resources, we find that the reallocation of resources and changes in the structure of production lead to a large increase in real gross domestic product (GDP) measured in equilibrium prices. Empirically, there are large efficiency gains to be realized by reallocating resources, even without assuming any unemployment of resources. We separately consider 
technological change (and choice of technique) and the impact of assuming that existing capital is less productive in the reformed economic environment.

\section{Technological Transfer}

Recent research suggests that the world is characterized by international technological spillovers. These are quite important in the case of developing countries which benefit from technological innovations abroad primarily transmitted through international trade in capital goods embodying these innovations. In the case of North Korea, the parameters estimated by Coe, Helpman, and Hoffmaister (1996) indicate that complete liberalization would result in a TFP gain of approximately 18 percent. ${ }^{17}$ In this case a sectorally uniform increase in TFP would be obtained. In a later section, we consider the possibility that North Korea converges toward South Korea technologically, involving a sectorally non-uniform increase in TFP, as well as changes in the input mix.

\section{Capital Obsolescence}

Finally, an important question involves the value after liberalization of the pre-existing capital stock. There are two points to consider. First, due to the putty-clay nature of technology, the capital stock accumulated under one set of output and factor prices is likely to be sub-optimal for different relative prices. While this is true for all economies, the impact is particularly acute for transition economies, where the relative prices under central planning have been at wild variance from those observed in world markets (and the notion of optimizing choice of technique with respect to factor prices has been of questionable relevance). Second, economies sheltered from international trade may manufacture products that are essentially worthless in world markets. Think of televisions or radios without tuners — both of which are produced in North Korea. To the extent that capital is product-specific, this capital would be effectively worthless

\footnotetext{
${ }^{17}$ This estimate is derived from a regression model relating TFP to imports of capital goods from developed countries, secondary school enrollments, and interaction terms.
} 
when the economy was opened up to trade. ${ }^{18}$

Sinn and Sinn (1992) report that one-half to two-thirds of East Germany's capital stock was worthless after unification. ${ }^{19}$ If lack of exposure to international trade is taken as a proxy for internal distortion, the North Korean economy is likely to be even more distorted than the East German economy was. On the basis of the East German experience, this shock was calibrated as one half to two-thirds of the value of the 1990 pre-opening capital stock in Noland, Robinson, and Scatasta (1997). In the current model, calibrated to 1996, the capital stock already has shrunk, and the obsolescence shock is assumed to be smaller at 25 percent. ${ }^{20}$

\footnotetext{
${ }^{18}$ This treatment is obviously a stylized one. One way to think of it is that there are goods with positive prices in autarchy and a world price of zero. When the economy is opened up, product specific capital would depreciate instantly.

${ }^{19}$ This of course depends on both output and factor prices on the one hand, and demand on the other. With respect to the former, Akerlof et al. (1991) argue that given the wage equalization strategy, a wage subsidy could have significantly increased the number of viable enterprizes in East Germany. With respect to the latter, East German consumers were well-acquainted with West German consumer goods at the time of unification, and it has been argued that this familiarity together with consumption transfers caused a temporary shift in preferences away from East German-produced goods. High wages and demand shocks may have contributed to the size of the "obsolescence shock" in the German case.

The particular relevance of these arguments in the Korean case is unclear. There is no reason to believe that under unification the Korean government would follow a policy of income or wage equalization as the Germans did (indeed Young, Lee, and Zang (1998) advocate the opposite) or under unilateral reform by an independent North Korea that the necessary resources for a wage subsidy would be available. Consequently, there is a counterargument that the North Korean capital stock might not decline as much as in the East German case. Three reasons are given. First, there is no reason to expect the Koreans to follow a wage equalization policy as the Germans did in the event of unification. Second, since the North Koreans are considerably more isolated than the East Germans, they are presumably less familiar with South Korean consumer goods and may not have access to consumption transfers on the scale the East Germans did. Moreover, it is possible that having observed the German case, in the event of a North Korean collapse, South Korean authorities would restrain their firms from flooding the North Korean market with consumer goods. All of these forces would encourage North Koreans to continue buying home goods, maintaining the value of the North Korean capital stock.

Second, the East Germans lost their major markets in other centrally planned economies, contributing to the decline in the capital stock. It has been asserted that China represents a viable market for cheap, low quality North Korean manufactured goods.

If one accepts these arguments, then one should focus on the previously described scenarios in which the value of the North Korean capital stock is implicitly maintained.

${ }^{20}$ There is anecdotal evidence that under the pressure of famine, North Korea has been dismantling its capital stock and bartering it with China as scrap in exchange for food.
} 


\section{Product Market Integration}

The key result is that the impact on South Korea of product market integration in the customs union scenario would have a very modest positive impact. ${ }^{21}$ Trade with North Korea would mostly substitute for trade with other countries and, given the small size of North Korea relative to South Korea, trade creation and diversion would have a trivial impact on South Korea. ${ }^{22}$ Only three sectors would experience percentage changes in output of more than one percent and South Korean GDP would rise by less than one half of one percent. ${ }^{23}$ Formation of the customs union would be a Pareto-improvement: returns to all factors would either increase or remain unchanged. The distributional implications would be trivial.

In contrast, formation of the customs union would amount to a significant movement toward free trade for North Korea relative to its previous external barriers. The share of trade in national income would more than triple, led by a tremendous increase in light manufactured exports. Trade with both South Korea and the rest of the world would increase, and from the standpoint of the whole peninsula, the customs union would be strongly trade creating. In North Korea, there would be enormous changes in the composition of output: light manufacting output would more than double, and construction activity would increase by more than half, while rice and capital goods production would fall significantly (Figure 1). Overall, the agriculture sector shrinks and more than two million workers leave agriculture for other employment, primarily in light manfacturing and construction. Despite the contraction of the agricultural sector, domestic food availability would improve however, rising from 3.2 million metric tons equivalent in the base to 7.4 million metric tons after the formation of the customs union. This would raise

\footnotetext{
${ }^{21}$ In the interests of parsimony, we report only the experiments in which North Korea undergoes complete liberalization and suffers an "obsolescence shock" reduction of one-quarter of its capital stock (unless otherwise indicated). In the customs union experiments and the monetary union experiments, where there is no capital mobility, we apply a uniform 18 percent increase in TFP. In the monetary union scenario, in which cross-border capital transfers occur, we report the North Korea adopting South Korean technology results unless otherwise noted.

${ }^{22}$ From the South Korean perspective, the customs union would create nearly $\$ 4$ billion in trade and divert less than $\$ 1$ billion from the rest of the world.

23 These are mining (-3.1 percent), other grains ( -1.4 percent), and light manufacturing ( -1.1 percent).
} 
domestic food availability from below the minimum human needs target of 3.7 million metric tons specified by the FAO/WPF/UNDP to above the 4.8 million metric tons normal human demand target (Figure 2). ${ }^{24}$ GDP would increase by more than one-third. Returns to capital and all classes of labor would rise; returns to land would fall. GDP for the peninsula as a whole would rise by 1.5 percent.

Economic integration could well be accompanied by a reduction in political tensions (or indeed, political integration). As an illustrative experiment we reduced military expenditures in North and South Korea to the Organisation for Economic Cooperation and Development (OECD) average of 2.5 percent of GDP. Again, for South Korea, this "peace dividend" would be relatively minor, less than $\$ 300$ million. ${ }^{25}$ However for the far more militarized North Korea, the impact would be much larger, adding another ten percent to GDP on top of the gains from formation of the customs union. In this scenario, North Korea would achieve the FAO/WFP/UNDP total normal demand target of 7.8 million metric tons. For the peninsula as a whole, the peace dividend would be 0.3 percent of GDP. Per capita income in the North would remain less than a tenth that in the South under this scenario.

\section{Factor Market Integration}

This basic story — large impact on North Korea, small impact on South Korea — would change considerably if factor markets were allowed to integrate. With exchange rate (monetary) unification, it is natural to expect the capital market, if not the labor market, to integrate. For heuristic purposes, however, we initially consider a hypothetical case in which the inter-Korean labor market integrates but the inter-Korean capital market does not (that is to say, labor flows from North to South, but capital does not flow in the other direction). This could happen if, for example, North Korea suddenly were to collapse à la East Germany before political

\footnotetext{
${ }^{24}$ This specification of "needs" or "demands" in physical terms without reference to prices or opportunity costs may strike economists as odd. This is the normal methodology used by relief agencies, however.

${ }^{25}$ This is the efficiency gain associated with military demobilization. The direct budgetary impact would be higher. Bae (1996) estimates that with unification, the elimination of duplicative intelligence operations, diplomatic missons, etc. might generate budgetary savings of around $\$ 500$ million for the peninsula as a whole.
} 
rapprochement and cross-border capital flows had occured. To examine this possiblity, we posit a case in which labor migrates until per capita income in the North is 60 percent that of the South, as has been done in previous literature. ${ }^{26}$ In this case, North Korea would be virtually depopulated (more than 90 percent of the population migrates) before the 60 percent per capita income target was attained. This extreme result serves to underscore the critical importance of generating capital inflows into North Korea. ${ }^{27}$

In the more plausible converse case, where capital flows North and North Korea adopts South Korean technology, but labor is not permitted to move South, nearly $\$ 700$ billion of new investment (more than a quarter of the South Korean capital stock) would be required to move in order to attain the per capita income target, underlining the implicit trade-off between capital and labor flows as equilibrating adjustment mechanisms. ${ }^{28}$

Having established the extreme bounds of cross-border factor mobility necessary to achieve the per capita income convergence target, we focus on an intermediate case in which there is a degree of cross-border movement in both labor and capital. Park (1997), on the basis of the German experience, estimated that with unification, two million North Korean workers might migrate South. Assuming that TFP increased by 18 percent, South Korea has to invest $\$ 541$ billion in the North (more than a fifth of the South Korean capital stock) for North Korea to attain the 60 percent per capita income target. ${ }^{29}$ If this transfer were to occur over ten years, it would

${ }^{26}$ This benchmark is derived from comparisons of inter-jurisdictional differences in levels of per capita income among South Korean provinces, US states, and members of the EU. It is thought of as a level of per capita income convergence sufficient to choke off the incentives for mass migration and to maintain social stability. It is used in this study to facilitate comparison with previous studies. See Noland (1997) for further discussion and citations.

${ }^{27}$ We have assumed that this migration solely takes the form of North Korea - South Korea migration. It is quite possible that in reality there might also be emigration to other destinations, in particular China. If this were the case, it would obviously effect the precise calculation of migration necessary to achieve the income convergence target.

${ }^{28}$ We have treated the capital movement as a pure grant. It is also possible to calculate the rents and impute them to South Korean national income as remitted profits, as is done in the following section.

${ }^{29}$ In the North, the increases in the capital-labor and land-labor ratios together with the increase in TFP, would generate a considerable increase in the North Korean agricultural wage which converges to the South Korean level. Urban wages in the North would remain significantly below the South Korean level, however. In 
imply a transfer of roughly ten percent of GDP annually — significantly higher than the amount in the German case.

In this scenario, real GDP would rise tremendously in North Korea and fall slightly in South Korea in response to these factor movements. Output would rise in all sectors in North Korea, except in the public administration and military sectors which, by construction, remain constant. Conversly, output would fall in all sectors in South Korea (except in public administration and the military).

However, the existence of cross-border factor flows raises the possibility that GDP could differ significantly from GNP if migrants were to remit wage income or if foreign investment were to generate repatriated profits. ${ }^{30}$ In the extreme case in which all incomes earned by migrants and foreign investment are remitted to their sources, profits from investment in the North largely would offset the negative impact in the South of the monetary union with the North. The North would still come out substantially ahead. Income for the combined Koreas would rise as the returns to factors are equalized in the two economies, with combined income exceeding the base by roughly 12 percent.

\section{Foreign Capital Inflow}

In the compartive static simulations thus far, the process of capital transfer literally amounts to taking capital from the South Korean capital stock and moving it north. It would be desirable to model external capital inflows as well. In the comparative statics set-up, one could model capital inflow as either an exogenous increase in the capital stock (which would not affect the current account balance) or as an exogenous increase in the trade or current account deficits

this sense the attainment in this scenario of the 60 percent per capita income target and the posited implications for cross-border migration and social stability may be a bit misleading: for most North Koreans, wage income would still be far less than earned by equivalent labor classes in the South.

${ }^{30}$ One could think of the transfer of capital from South to North Korea taking the form of grants or private investment. In the former case, capital would be transferred to the North, and there it would remain, providing economic benefits to the Northern economy. In the latter case, Southern investors would retain ownership, and the investments would yield a stream of remitted profits adding to Southern income. In the event of unification, actual transfers would probably reflect a mix of grants (perhaps funding public infrastructure) and private profitmaking investments (factories, etc.). 
(which would not affect the capital stock). One could think of the latter as representing the moment imported capital goods are purchased, and the former as representing the moment they are installed.

In the extreme case, all investment in North Korea could come from abroad. In this scenario, more than $\$ 600$ billion of capital inflow (together with the emigration of two million workers) would be necessary to reach the per capita income target. (More capital would be necessary than in the previous internal transfer case since the South Korean capital stock would be unaffected and as a consequence South Korean per capita incomes would be higher in this scenario.)

A key issue is how the inflow of foreign capital would affect the real exchange rate. To explore this issue, we took the unified exchange rate and subjected it to a series of trade balance shocks that would leave the measured capital stocks in the two countries unaffected. (These should be thought of as medium-to-long run effects, abstracting from short-run monetary shocks that the KIM is poorly suited for modeling.) The experiments are summarized in Figure 3, which depicts the real exchange rate appreciation in response to foreign capital inflows. Suppose the $\$ 600$ billion inflow were to occur at a steady linear rate over a decade (i.e. $\$ 60$ billion annually). As the real exchange rate appreciated, the level of output in the South Korean traded-goods sectors would fall, while the non-traded goods sectors (construction and services) would exhibit increases in output (Figure 4). (Public administration and the military are fixed by assumption and show no output response.) The real exchange rate appreciation would also adversely affect the traded-goods sector in North Korea, though some traded-goods sectors such as light manufacturing and mining would continue to register significant increases in output relative to the highly distorted base (Figure 5).

\section{CONVERGENCE}

Thus far the process of economic integration has been analyzed using comparative static models to examine a number of key issues. The integration process, however, is inherently temporal, as investment and technological upgrading cannot occur instantaneously. Moreover, in the previous section, technological change was treated as a sectorally uniform process, and the 
amount of TFP increase was calibrated from the work of Coe, Helpman, and Hoffmaister.

However, the specific case in hand may differ fundamentally from the generic phenomenon they analyzed. For the purposes of their regression model, Coe, Helpman, and Hoffmaister classify South Korea as a developing country. Thus no technological spillovers would be attributed to North Korea importing capital goods from the South. Moreover, in the exchange rate unification/monetary union simulations, we allowed cross-border factor flows; in particular, we allowed capital to move from South to North Korea. In this case, it would be plausible to expect that the North would adopt South Korean technology embodied in the capital. The rationale is that as the two economies integrated, the relative price structure of North Korea, the smaller economy, would begin to converge toward that of the larger economy, South Korea. Moreover, as new plants in North Korea were built using South Korean capital, and new production technologies were adopted in North Korea, this process would change the allocation of basic inputs and produced intermediates. As South Korean techniques become the norm, the input-output coefficients in the North should converge to those of the South. These coefficients would be presumably optimal given the existing factor prices and distortions in South Korea, so their adoption by North Korea would imply the elimination of internal distortions which we are unable to model explicitly. ${ }^{31}$ Operationally, the North's production function shift parameter (its productivity level) increases to the level of the South's, and the North adopts South Korea's intermediate input mix in the form of the South's input-output coefficients. ${ }^{32}$

The critical question is how rapidly this convergence occurs. The standard result from Barro and Sala-i-Martin $(1992,1995)$ is that, conditional on a variety of other factors, per capita income in poorer regions tends to converge on per capita incomes in richer areas at around two percent annually. Yet one might expect the rate of convergence after a fundamental regime change to be faster than the steady states analyzed by Barro and Sala-i-Martin. Once again we

\footnotetext{
${ }^{31}$ One could also rationalize the linkage of capital investment and productivity convergence along the lines of the management perspective of Dyck (1997) who argues that in the German case, replacement of East German managers with West German managers was key to enterprize rehabilitation and viability.

${ }^{32}$ Noland, Robinson, and Liu (1999) contains a decomposition, a graphical explication, and some modeling results pertaining to these two effects. In the interests of brevity, we only report the case in which North Korea adopts South Korean technology in this paper.
} 
turn to the literature on German unification and find that the estimates of the speed of East German technological convergence vary enormously, with upper end estimates of technological convergence on the order of ten to 12 percent annually. ${ }^{33}$

The economic implications of this uncertainty is illustrated in Figure 6 where we ran the model imposing from two to twelve percent annual technological convergence, with both the sectoral level of TFP and the input-output mix in North Korea converging to the South Korean norm over a period of ten years. We then calculated the amount of capital transfer necessary to reach the 60 percent benchmark. Of course, this calculation assumes that the rate of technological convergence and the volume of capital flows are independent - at least above an investment threshold. As shown in Figure 6, assuming two percent technological convergence and no labor migration, it would take more than $\$ 600$ billion in investment in the North to reach the 60 percent benchmark after ten years. This figure falls by more than half, to less than $\$ 300$ billion, if twelve percent convergence is assumed. Indeed, convergence rates of less than ten percent imply larger transfers as a share of GDP than in the German case. ${ }^{34}$

This treatment is not fully satisfactory for two reasons. The previous treatment is inadequate in that it is not a true dynamic model - it is simply the imposition of a temporal pattern of technological change on the comparative statics model, and choice of a ten-year period is arbitrary (though Kwon (1997) argues that this was sufficient for convergence in Germany). Furthermore, as demonstrated in the previous section, labor migration can act as a substitute for capital investment, and migration must be taken into account in estimating investment requirements. So for our final set of experiments, we specified a simple recursive dynamic model in which labor force growth is set on the basis of demographic projections, capital is accumulated

\footnotetext{
${ }^{33}$ See Hughes Hallet and Ma (1992), Burda and Funke (1993), Herz and Roger (1995), Sinn (1995), Schalk and Untiedt (1996), Boltho, Carlin, and Scaramozzino (1997), Keller (1997), and Rummel (1997). The estimates of convergence appear to vary for two reasons. First, it is difficult to disentangle productivity gains from the large increase in public and private investment in East Germany that occurred post-unification. Second, the sample period is relatively short. Hence the coefficient estimates appear to be sample and specification sensitive.

${ }^{34}$ This comparison is a bit inexact in that the transfers in the German case are measured as public transfers, while in our case the figure could include private investment flows.
} 
as a constant share of output, and the rate of TFP change is set exogenously. ${ }^{35}$

Suppose that monetary (exchange rate union) occured instantaneously in 1996 (the year for which the model is calibrated) and over the course of ten years two million North Koreans migrated to South Korea, technological convergence occurred at the mid-range estimate of six percent a year, and a portion of South Korean capital accumulation is invested in the North until the rate of return on capital equalized in the two Koreas. ${ }^{36}$ This would imply a $\$ 641$ billion transfer over ten years or about 11 percent on South Korea's annual GDP — significantly more than the value of public transfers in the German case.

As shown in Figures 7 and 8, this scenario would amount to a tremendous (to the point of implausibility) positive shock to the North Korean economy, a modestly negative shock to the South Korean economy, and a moderately positive shock from the perspective of the peninsula as a whole. At the end of ten years, output would be around seven percent higher than under the baseline projection. In South Korea, monetary union and cross border factor flows would reduce the rate of GDP growth in South Korea by about one percent a year. If one were to attribute all migrants income to North Korea and assume that all profits on investment in the North were repatriated to South Korea, then the impact would be moderated, and the growth rate of South Korean GNP would fall by only about one half of one percent.

This result raises the issue of distribution. There are three ways to think about the distributional effects in this set-up: comparisons between North and South Korea, comparisons between the outcomes after economic integration relative to the 1996 base, and comparisons

\footnotetext{
${ }^{35}$ The labor force growth of the two economies was set exogenously on the basis of economically active labor force projections released by the Ministry of National Unification. TFP growth rates were set exogenously on the basis of econometric estimates. Capital accumulation was calibrated to reproduce the pattern of economic growth observed over the period 1991-1996. The KIM is essentially a long-run equilibrium model and is not designed to capture short-run cyclical effects. We assume that the cross-border factor flows occur at a constant rate over the course of a decade. In reality, these could occur with considerable abruptness. Endogenization of the cross-border factor flow is an obvious direction for future research.

${ }^{36}$ We assumed that the transfers to the North come completely at the expense of investment in the South (i.e. there is complete crowding out of investment, and no crowding out of consumption or foreign direct investment). This scenario would generate a bit more slowing of South Korea's rate of capital accumulation and growth rate than if investment in the North were allowed to crowd out all components of absorption. In this experiment we ignore the role of foreign capital which was discussed in the previous section.
} 
between these outcomes to what is projected absent integration. The first is the simplest and possibly the most important: rates of return for capital and labor would (partly) converge between North and South Korea, but the convergence is not sufficient to attain the 60 percent per capita income target (Figure 9). (The ratio of per capita incomes at the end of the period would be about 55 percent.) This result implies that, even in this relatively optimistic scenario, per capita income in North Korea would remain well below the level in South Korea for an extended period of time, implying either some method of restraining migration, or alternatively, higher levels of migration than contemplated in this experiment. Indeed, under the assumptions of a six percent rate of technological convergence and two million migrants, the capital transfer necessary to hit the 60 percent per capita income target would drive the rate of return on capital in North Korea below that in South Korea. If a more rapid rate of technological convergence (say, 12 percent instead of six percent) is assumed, it wold be possible to attain the 60 percent target before the rates of return on capital were equalized. Allowing some of the North Korean capital accumulation to be financed by foreign capital inflows would reduce the direct burden on South Korean, but make achieving the 60 percent target more difficult. It would mean less crowding out of South Korean domestic investment, more rapid South Korean growth, and, as a consequence, a higher level of target income.

In South Korea, economic integration with North Korea would generate a shift in income away from labor and toward capital, regardless of whether transfers to the North were considered grants or profit-making investments, and within labor away from low-skilled groups and toward higher skilled groups (Figure 10). To the extent that high-skill labor groups tend to be the predominate owners of capital, this result implies that, absent some compensatory redistribution policies, the process of economic integration would be accompanied by increased income and wealth inequality in the South. In comparison to the no-integration base, all classes of labor would lose. However, compared to the base of 1996, the wages of low-skill labor would fall, while the wages of high-skill would labor rise (albeit less than in the no integration scenario). Capital would benefit in both comparisons. As a consequence, these distributional implications would likely be apparent to those concerned. 


\section{CONCLUSION}

Previous work (Noland, Robinson, and Liu; 1998) examined the possibility of Paretoimproving economic integration on the Korean peninsula. This relatively optimistic result crucially depended on two modeling assumptions. First, it depended on the assumption that the form of capital transfer to the North took the form of profit-making investment, which yielded a stream of remitted profits to Southern investors, and second that technological convergence between the North and the South was relatively rapid.

This paper has taken a second look at these issues, using more recent data on the North Korean economy unavailable at the time of the Noland, Robinson, and Liu work, and calibrating the rate of technological convergence in the updated model on the basis of estimates of convergence in the German case. The availability of new data has also facilitated the examination of famine-related issues and the possibility of a "peace dividend" associated with military demobilization which were not addressed in the earlier literature.

The main finding of this paper is that economic integration between North and South Korea would have enormous effects on the North Korean economy. Formation of a customs union between North and South Korea, for example, would represent a significant movement toward free trade on the part of the North, bringing with it a variety of benefits. The effects of the ongoing famine, for example, could be ameliorated through this approach. If economic integration were accompanied by military demobilization, the highly militarized North Korean economy would experience a significant peace dividend as well.

With regard to South Korea, product market integration would have a trivial impact. However, factor market integration could have a significant effect on South Korea, in terms of the composition of output, the distribution of income, and the rate of economic growth. Depending on the magnitude of capital inflows from the rest of the world (and the degree of real exchange rate appreciation), the nontraded goods sectors could expand at the expense of the traded goods sectors.

Assuming that the rate of technological convergence was in the middle range of estimates from the German literature, with gradual equalization of rates of return on capital between the two economies and with a reasonable amount of cross-border migration, per capita incomes in the 
North would still only reach 55 percent those of the South at the end of a decade. Indeed, under these assumptions, the amount of capital investment necessary to raise Northern per capita incomes to 60 percent those of the South would actually drive the rate of return on capital in the North below that in the South. However, it would be possible to attain the 60 percent target without such equalization of the rate of return in the two parts of Korea under high-end estimates of the speed of technological convergence. This suggests that either the rate of technological convergence would have to be very rapid (say, 12 percent annually), or restriction on migration from the North to the South would have to be imposed on a semi-permanent basis.

In South Korea, economic integration with North Korea would generate a shift in income away from labor and towards capital, regardless of whether transfers to the North were considered grants or profit-making investments, and within labor away from low-skill groups and toward high- skill groups. This suggests that absent some compensatory redistribution policies, the process of economic integration would be accompanied by increased income and wealth inequality in the South. Indeed, in the dynamic simulations, high-skilled workers would experience rising wages, while wages paid to lower skilled labor would fall.

This paper could be considered an example of rigorous speculation in that we have attempted to bring to bear rigorous technical methods to an important issue where the existent data is fragmentary and in all likelihood error-ridden. We have attempted to avoid spurious precision. What the model documents is that the process of Korean economic integration would involve some significant trade-offs, and we have attempted to document where the "large numbers" would be found. The robustness of the results are obviously an issue in any such exercise, and through the design of our experiments and scenarios, we have attempted to convey a sense of which results are likle to be more robust and which are likely to be less so. 
Figure 1. Composition of Output Change in North Korea

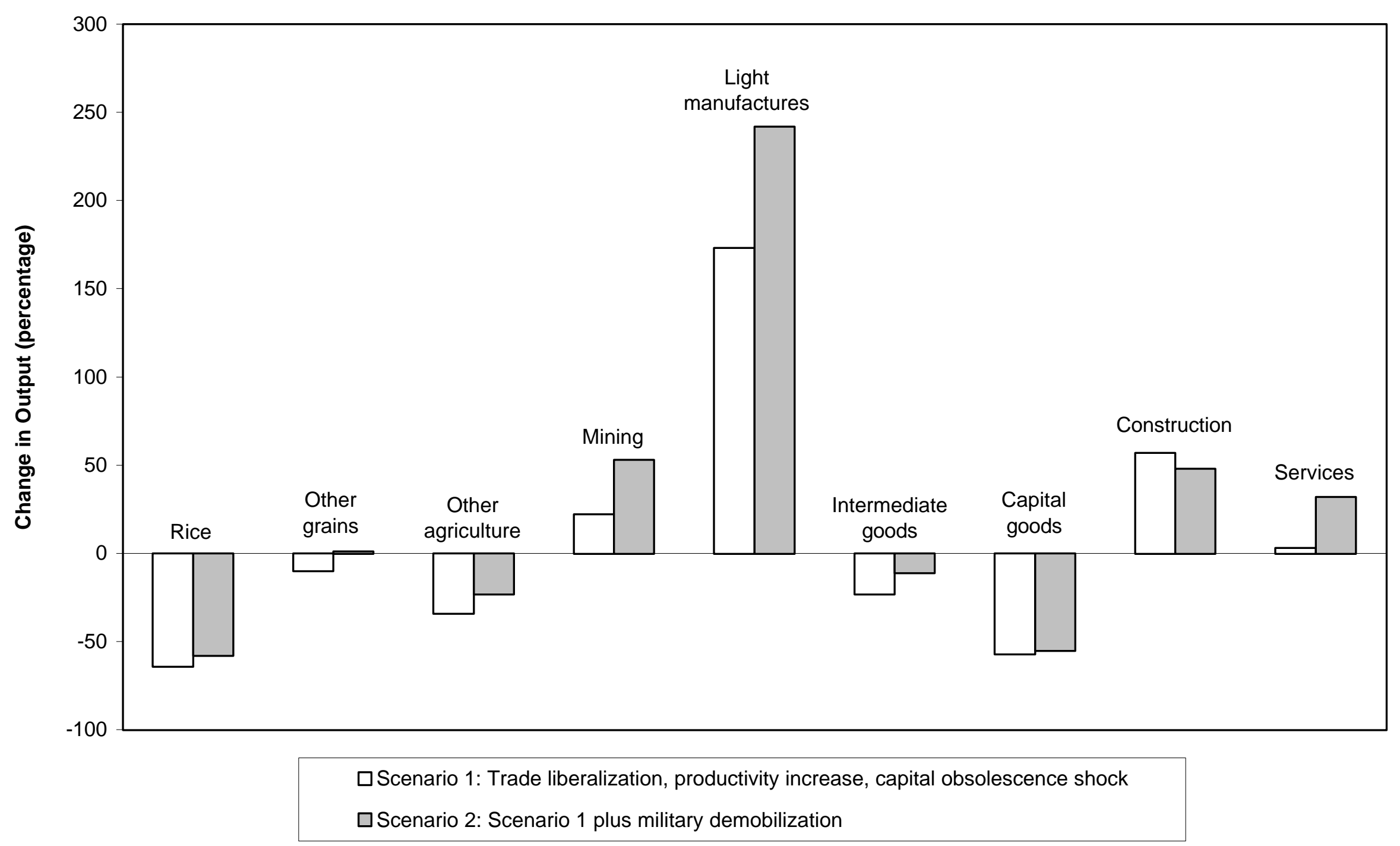


Figure 2. North Korean Food Availability

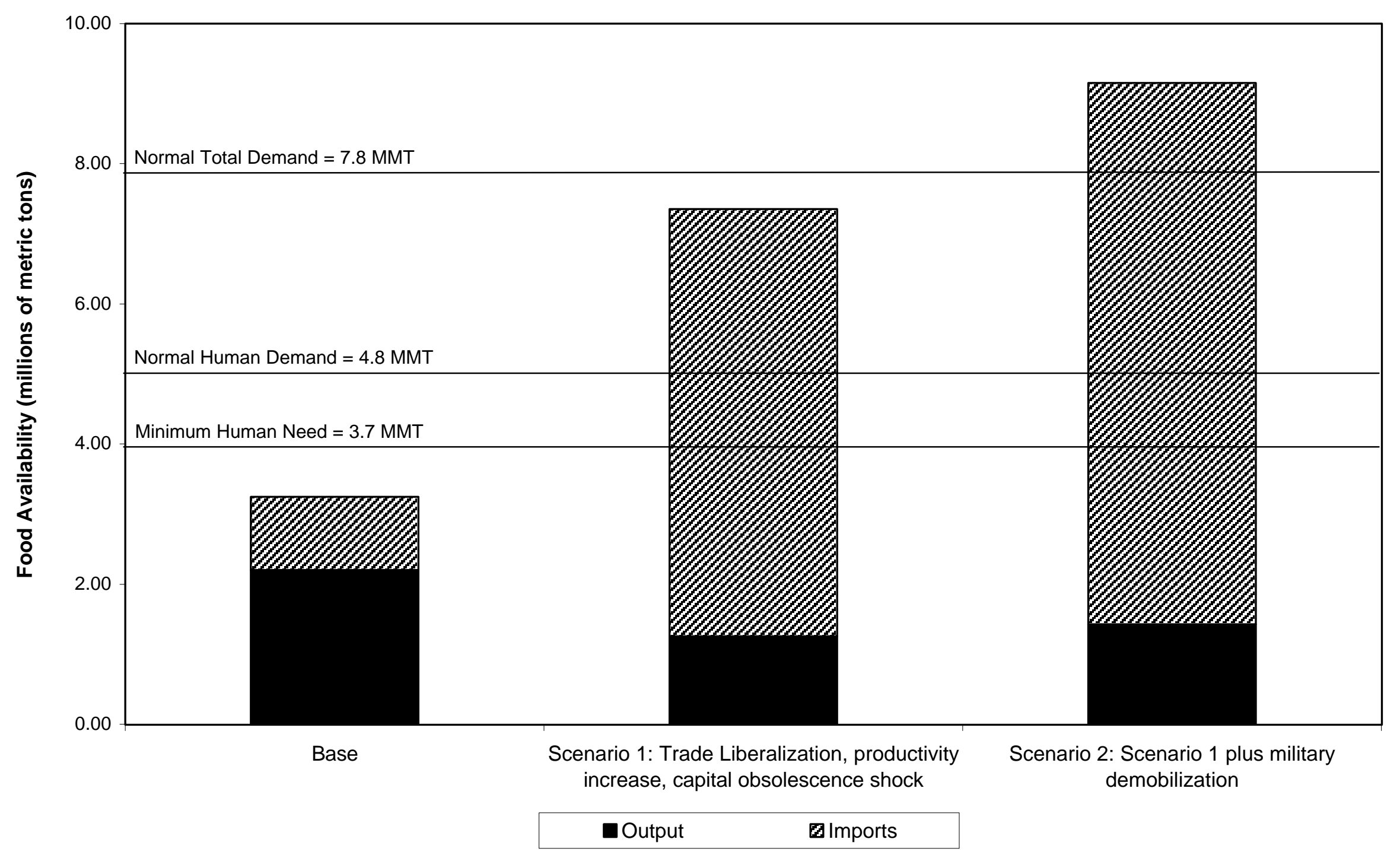


Figure 3. Capital Inflow and Exchange Rate Appreciation

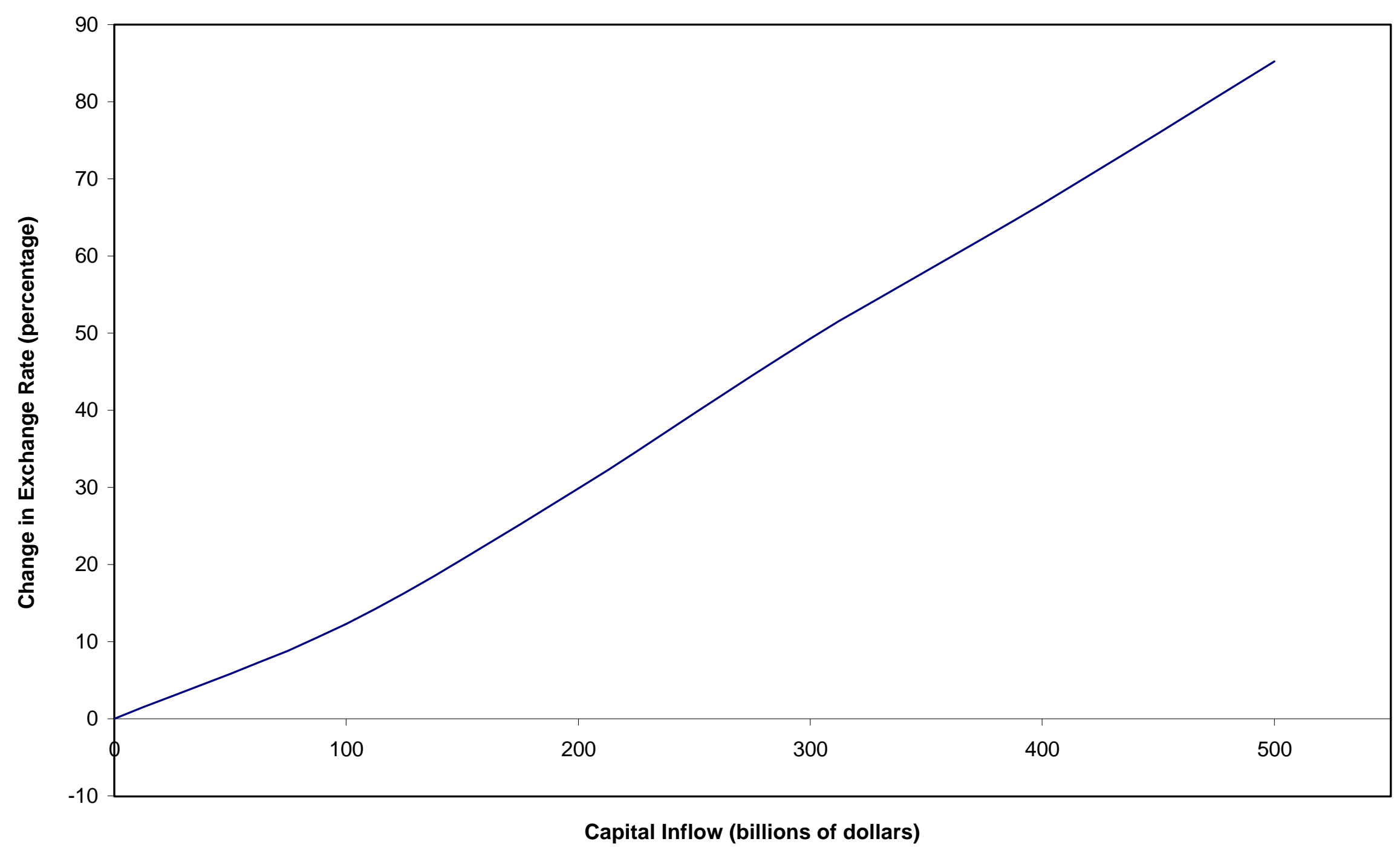


Figure 4. External Capital Inflow Case: Composition of Output Change in South Korea

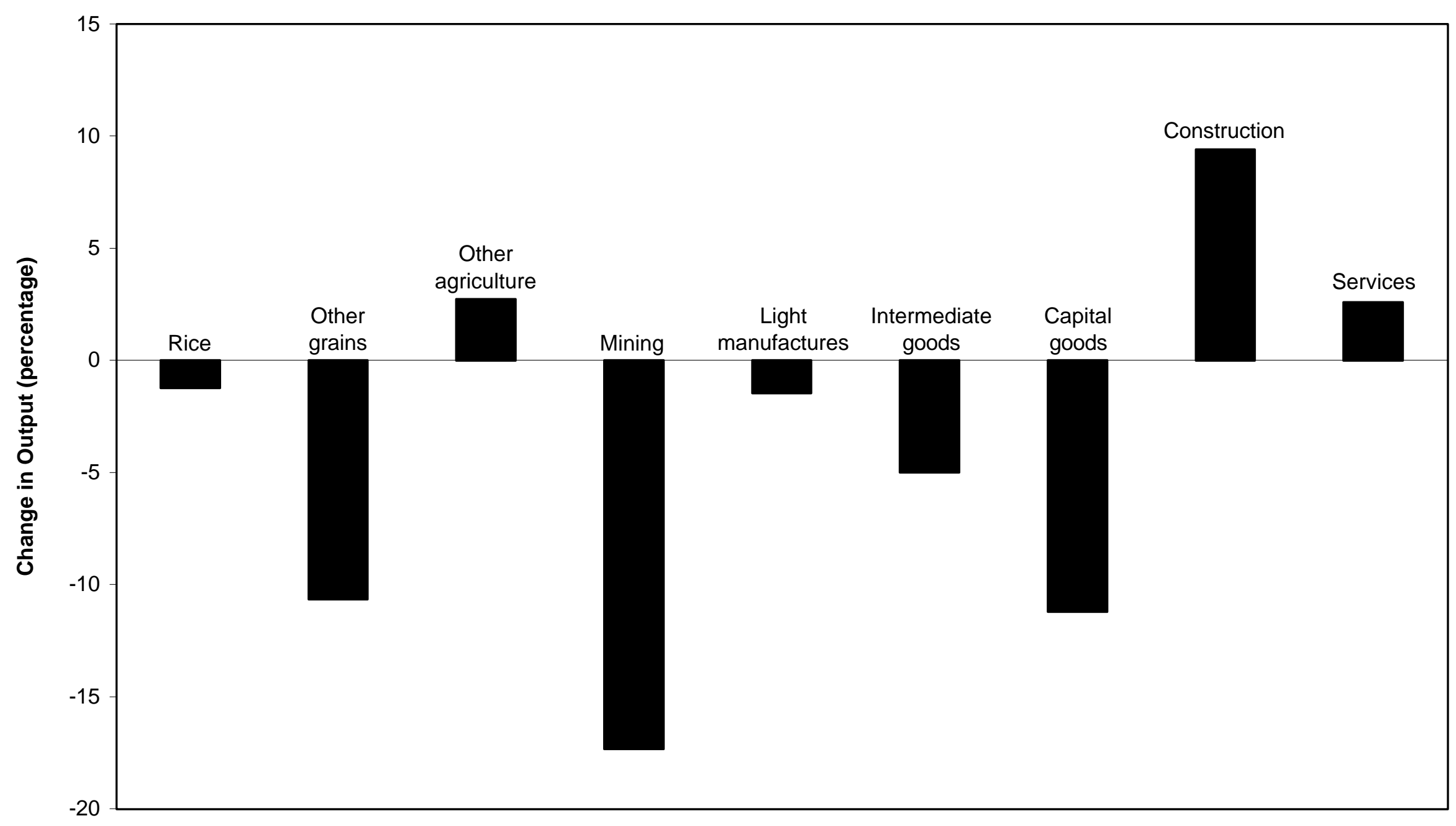


Figure 5. External Capital Inflow Case: Composition of Output Change in North Korea

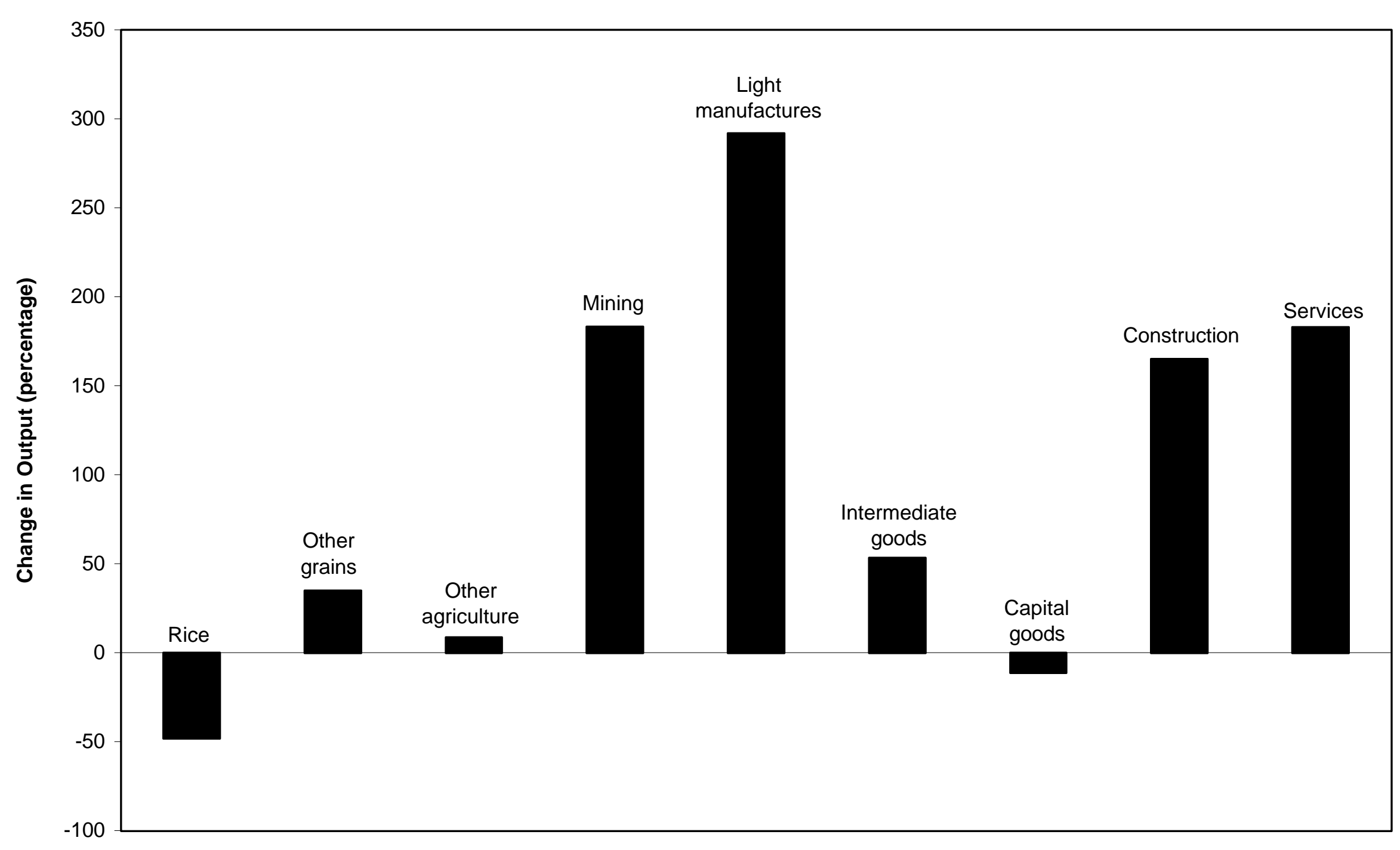


Figure 6. Rate of Convergence and Capital Investment Requirement

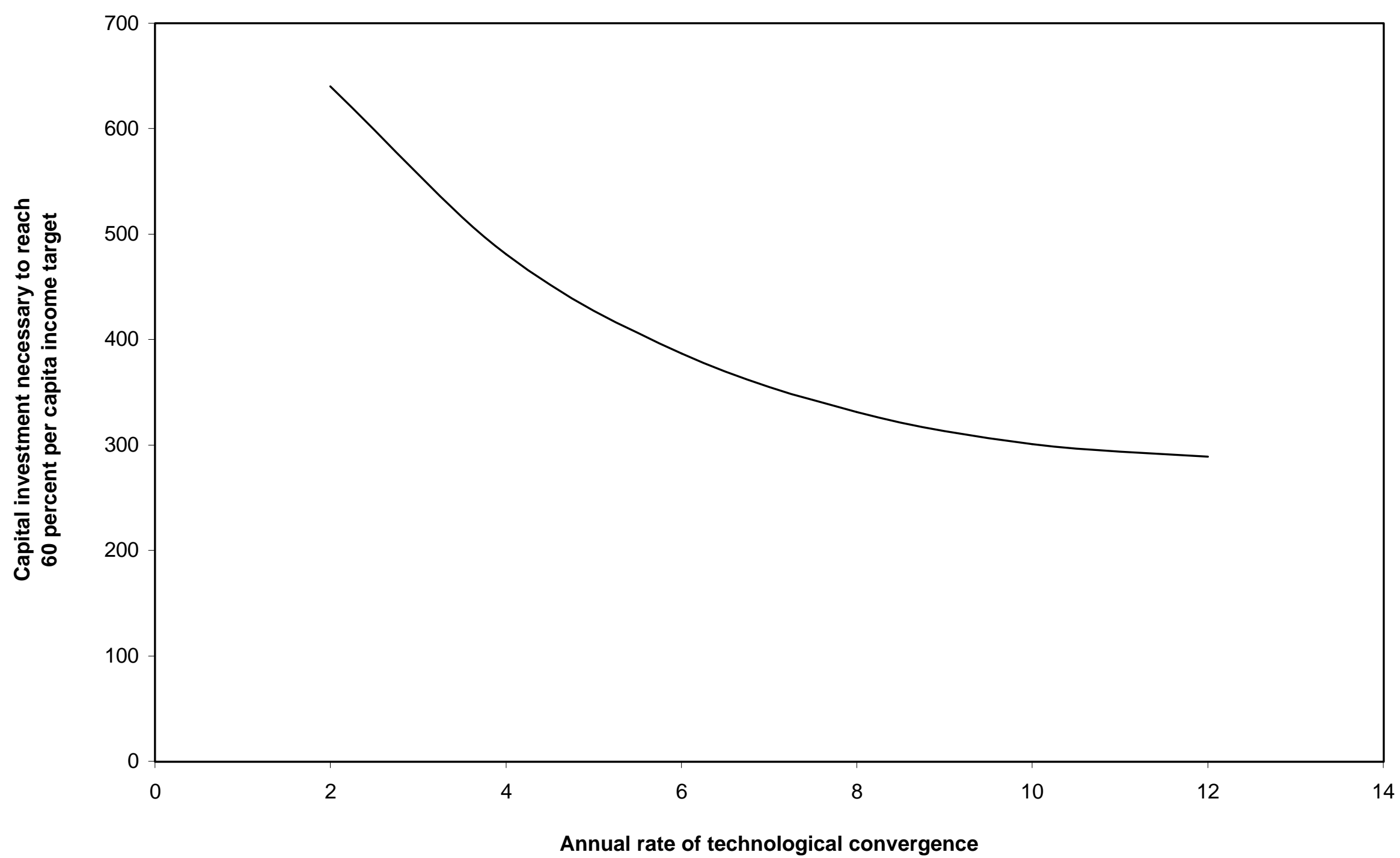


Figure 7. North Korea: GDP and GNP

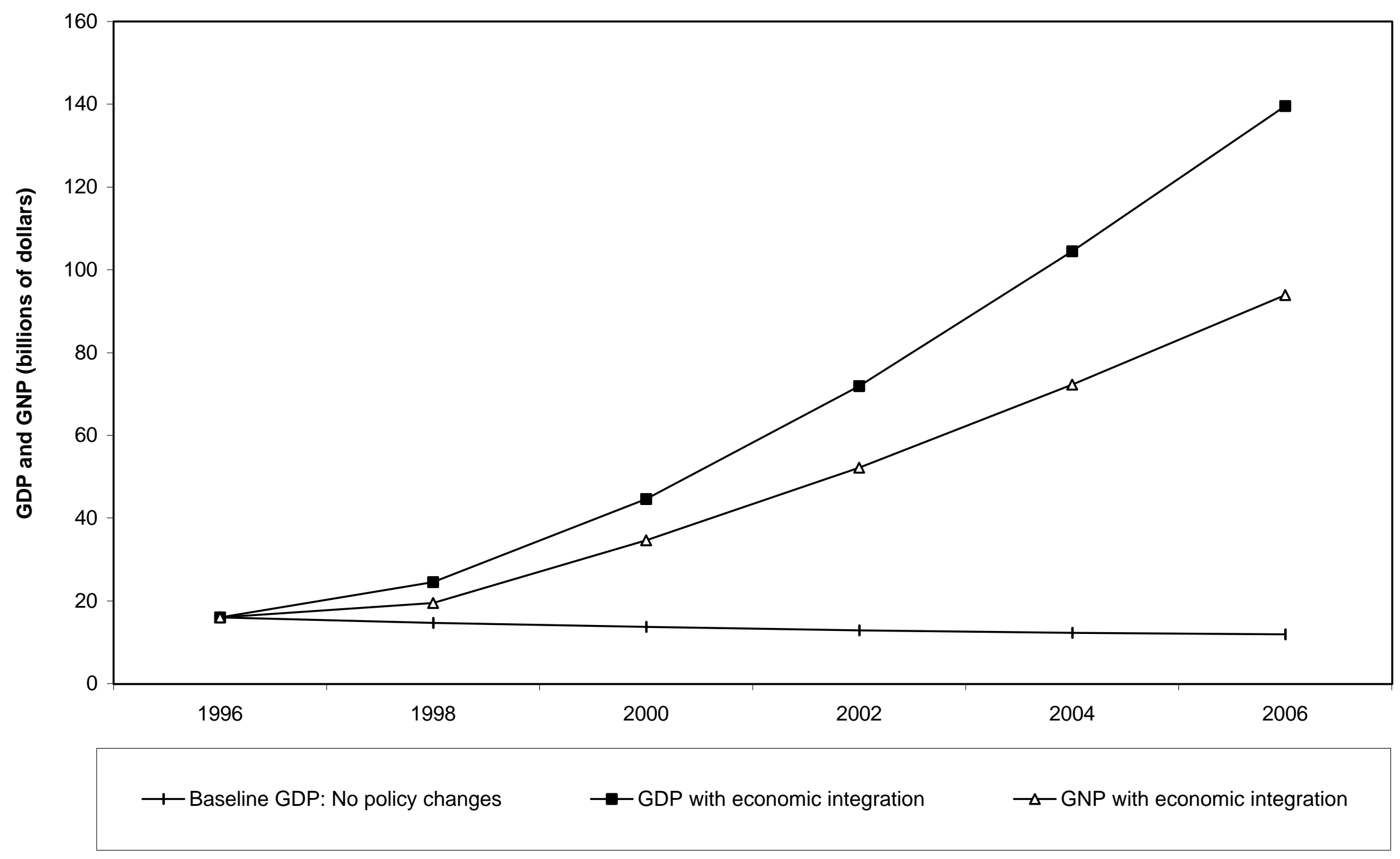


Figure 8. South Korea: GDP and GNP

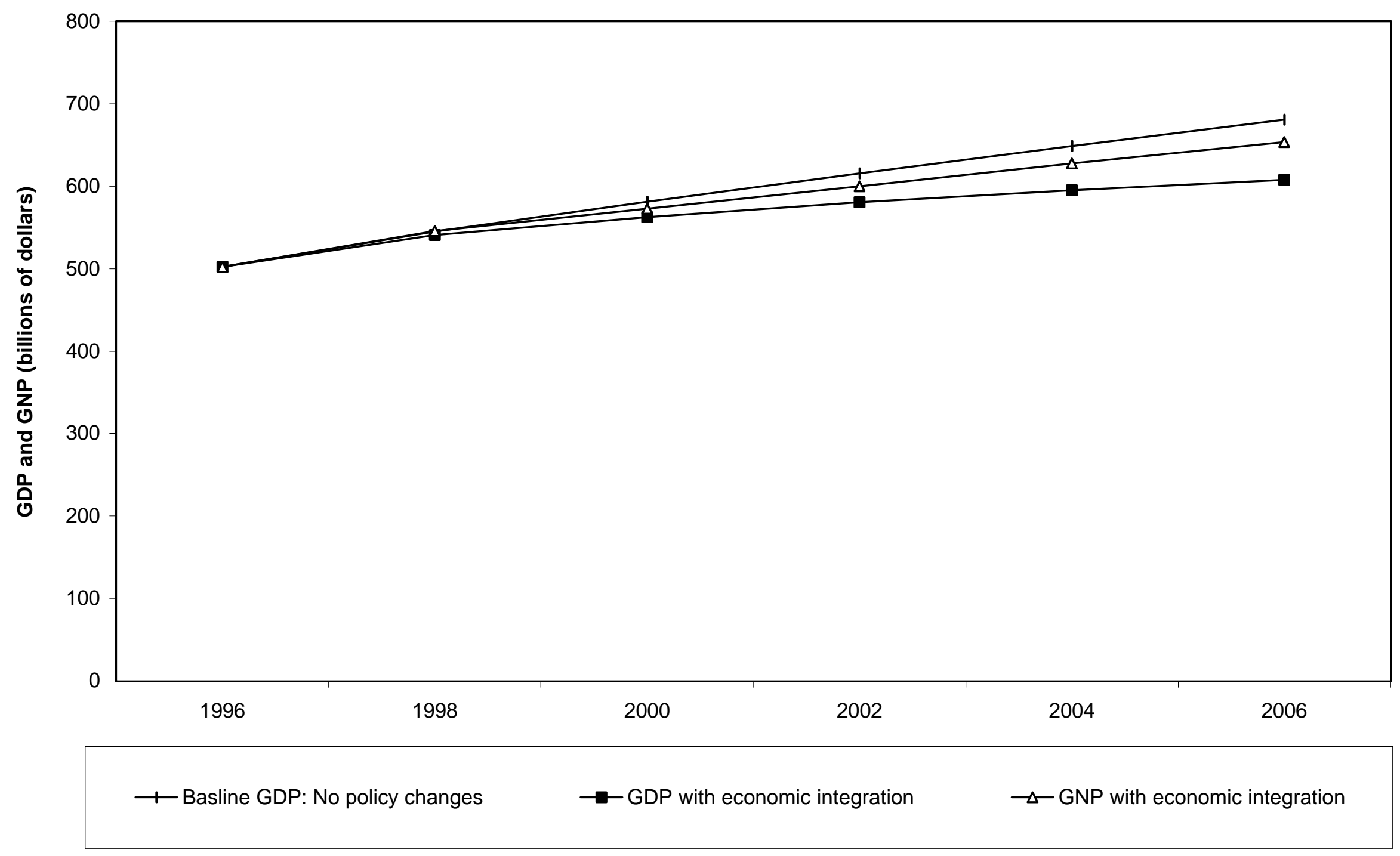


Figure 9. Factor Return Equalization

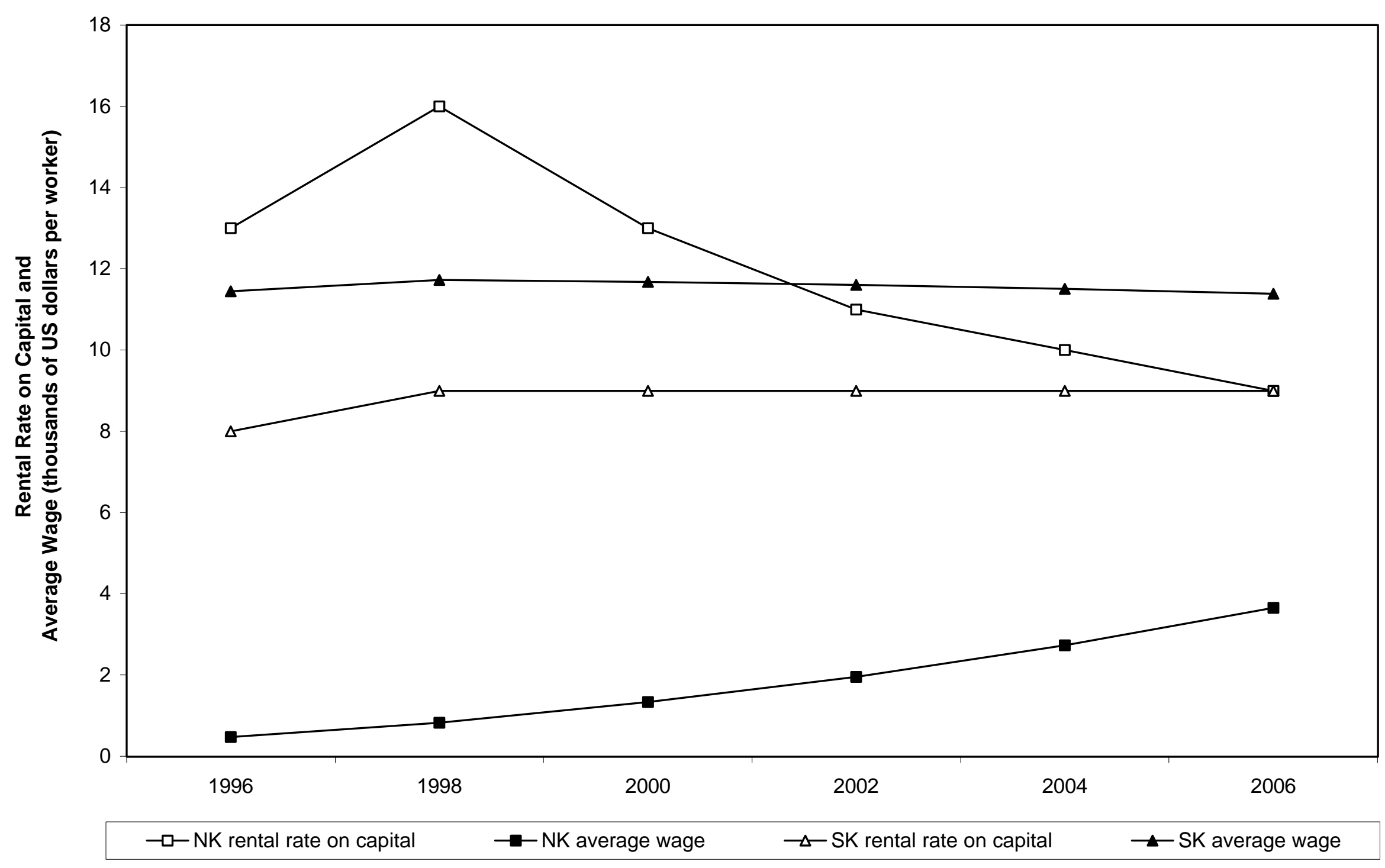




\section{APPENDIX 1: SOCIAL ACCOUNTING MATRICES}

The KIM utilizes two main databases for North Korea, a macroeconomic and a microeconomic Social Accounting Matrix (SAM) of North Korea for 1996. A SAM is a consistent array of economic transactions among agents that reconciles the input-output and national accounts. ${ }^{37}$ Each non-zero cell in the SAM represents the value of an economic transaction between actors. The accounts of the SAM define the transactions and income flows among five basic actors in the economy: producers/enterprises, households, government, capital account and the rest of the world. The input-output notion of inter-industry linkages is generalized to the idea that each actor's purchase is another actor's sale. Any flow of money from one actor to another is recorded in the SAM as a payment by some actor (the column) to some other actor (the row). The SAM also generalizes the national income accounting notion that income equals expenditure. The SAM must in fact be balanced: the total sum of each column must be equal to the total sum of each row, so that a budget constraint is imposed on each productive sector, labor category, household type and so forth. This means that (1) costs (plus distributed earnings) exhaust revenues for products, (2) expenditure (plus taxes and savings) equals income for each agent, and (3) demand equals supply for each commodity.

The SAM is divided into a number of blocs. The Activities bloc describes the costs and revenues for domestic producers. In the columns, the producers buy intermediate inputs, make value-added payments to primary factors, and transfer indirect, value-added and export taxes to (or receive subsidies from) the government. In the rows, they sell goods on domestic and foreign markets. The Commodities bloc describes markets for final products. The row describes sales on the domestic market, distinguishing between intermediate, consumption and investment demand. The column identifies absorption, which equals the value of domestic products sold on the domestic markets plus imports (valued at world prices), consumption taxes, value-added taxes and tariffs. The Factors bloc describes value-added payments to primary factors (in the row) and their distribution to specific institutions (enterprises, households, and government) plus the payment of direct factor taxes (in the column). The remaining blocs describe transfers among institutions.

\footnotetext{
${ }^{37}$ For a detailed treatment of Social Accounting Matrices see Pyatt and Round (1985), Stone (1986), or Devarajan, Lewis and Robinson (1994).
} 


\section{APPENDIX 2: STRUCTURE OF THE KIM-CGE MODEL}

Solving the CGE Model

The two-country CGE model presented here has been developed and solved using a package called the General Algebraic Modeling System (or GAMS). ${ }^{38}$ To a great extent, the GAMS representation of model equations is easily read as standard algebraic notation. Subscripts indicating countries, sectors, or factors appear in parentheses $\left[\mathbf{X}_{\mathbf{i j}}\right.$ becomes $\left.\mathbf{X}(\mathbf{i}, \mathbf{j})\right]$, and a few special symbols are used to indicate algebraic operations [ $\Sigma$ becomes SUM, $\Pi$ becomes PROD]. For example, the Cobb-Douglas consumer price index equation:

$$
P I N D C O N=\prod_{i} P C_{i}^{p w t c_{i}}
$$

is represented in GAMS as:

\section{PINDCON $=\operatorname{PROD}\left(\mathrm{I}, \mathrm{PC}(\mathrm{I})^{* *}\right.$ pwtc $\left.(\mathbf{i}, \mathrm{k})\right)$}

where PROD stands for the product operator $\Pi$, the $\mathbf{I}$ at the left of the parenthetic expression is the sectoral index over which summation occurs, and the two asterisks (**) indicate exponentiation. ${ }^{39}$

Table I lists the countrywide, sectoral, and factor classifications used in the model, as well as identifying the sectoral subsets that are needed in the equations of the model. Table II contains the variable definitions used in the CGE model. Table III contains the parameter definitions that appear in the model equations.

\footnotetext{
${ }^{38}$ GAMS is designed to make complex mathematical models easier to construct and understand. In our case, we use it to solve a large, fully-determined, non-linear CGE model (where the number of equations and number of variables are equal), although GAMS is suitable for solving linear, non-linear, or mixed integer programming problems as well. For a thorough introduction to model-building in GAMS, see Brooke, Kendrick, and Meeraus (1988).

${ }^{39}$ There are a few other syntax rules and conventions that appear in the equations shown below. The " $\$$ " introduces a conditional "if" statement in an algebraic statement. For example, PM(i,k,cty1)\$imi $(\mathrm{i}, \mathrm{k}, \mathrm{cty} 1)=\mathrm{xxx}$ will carry out the expression shown for all PM(i,k,cty1) that belong to the set imi(i,k,cty1); in other words, calculate an import price for all sectors in which there are imports.
} 
Table I: Variables in the KIM-CGE Model

\begin{tabular}{|c|c|c|c|}
\hline \multicolumn{2}{|l|}{ Price block } & \multicolumn{2}{|c|}{ Income and expenditure block } \\
\hline $\operatorname{EXR}(k)$ & Exchange rate & $\mathrm{CDD}(\mathrm{i}, \mathrm{k})$ & Private consumption demand \\
\hline GDPDEF(k) & GDP deflator & CONTAX(k) & Consumption taxes \\
\hline $\mathrm{PC}(\mathrm{i}, \mathrm{k})$ & Consumption price of composite good & DST(i,k) & Inventory investment demand \\
\hline $\mathrm{PD}(\mathrm{i}, \mathrm{k})$ & Domestic prices & ENTSAV(k) & Enterprise savings \\
\hline \multirow[t]{2}{*}{$\operatorname{PDA}(\mathrm{i}, \mathrm{k})$} & Processors actual domestic sales price & $\operatorname{ENTAX}(\mathrm{k})$ & Enterprise taxes \\
\hline & including subsidy & ENTT(k) & Government transfers to enterprises \\
\hline PE(i,k,cty1) & Domestic price of exports & $\operatorname{ESR}(\mathrm{k})$ & Enterprise savings rate \\
\hline $\operatorname{PEK}(\mathrm{i}, \mathrm{k})$ & Average domestic price of exports & $\operatorname{EXPTAX}(k)$ & Export tax revenue \\
\hline $\operatorname{PINDEX}(\mathrm{k})$ & Output price index & FBAL(k) & Overall current account balance \\
\hline PINDOM(k) & Domestic good price index & FBOR(k) & Foreign borrowing by government \\
\hline PINDCON(k) & Consumer price index & FKAP(k) & Foreign capital flow to enterprises \\
\hline PM(i,k,cty1) & Domestic price of imports & FSAV(k,cty1) & Bilateral net foreign savings \\
\hline $\mathrm{PQ}(\mathrm{i}, \mathrm{k})$ & Price of composite goods & FSAVE(k) & Foreign savings \\
\hline $\operatorname{PREM}(\mathrm{i}, \mathrm{k})$ & Premium income from import rationing & FTAX $(k)$ & Factor taxes \\
\hline PVA(i,k) & Value added price including subsidies & $\mathrm{GD}(\mathrm{i}, \mathrm{k})$ & Government demand by sector \\
\hline PVAB(i,k) & Value added price net of subsidies & GDTOT2(k) & Government nonmilitary \\
\hline PWE(i,cty1,cty2) & World price of exports & & consumption \\
\hline PWM(i,cty1,cty2) & World price of imports & GOVSAV(k) & Government saving \\
\hline $\mathrm{PX}(\mathrm{i}, \mathrm{k})$ & Average output price & GOVREV(k) & Government revenue \\
\hline \multirow[t]{2}{*}{ TM2(i,k,cty1) } & Import premium rates & $\operatorname{HHT}(\mathrm{k})$ & Government transfers to households \\
\hline & & HSAV(k) & Aggregate household savings \\
\hline Production block & & $\operatorname{HTAX}(\mathrm{k})$ & Household taxes \\
\hline $\mathrm{D}(\mathrm{i}, \mathrm{k})$ & Domestic sales of domestic output & $\mathrm{ID}(\mathrm{i}, \mathrm{k})$ & Investment demand (by sector of origin) \\
\hline $\mathrm{E}(\mathrm{i}, \mathrm{cty} 1, \mathrm{cty} 2)$ & Bilateral exports & $\operatorname{INDTAX}(\mathrm{k})$ & Indirect tax revenue \\
\hline $\mathrm{EK}(\mathrm{i}, \mathrm{k})$ & Aggregate sectoral exports & MPS(hh,k) & Savings propensities by households \\
\hline INT(i,k) & Intermediate demand & REMIT(k) & Remittance income to households \\
\hline M(i,cty1,cty2) & Bilateral imports & TARIFF(k,cty1) & Tariff revenue \\
\hline $\mathrm{Q}(\mathrm{i}, \mathrm{k})$ & Composite goods supply & $\operatorname{VATAX}(\mathrm{k})$ & Value added taxes \\
\hline SAD2(i,k) & Super AD2 parameter & $\mathrm{YH}(\mathrm{hh}, \mathrm{k})$ & Household income \\
\hline \multirow[t]{2}{*}{ SMQ(i,k,cty1) } & Import value share in total sectoral & YINST(ins,k) & Institutional income \\
\hline & Demand & $\mathrm{ZFIX}(\mathrm{k})$ & Fixed aggregate real investment \\
\hline $\mathrm{X}(\mathrm{i}, \mathrm{k})$ & Domestic output & ZTOT(k) & Aggregate nominal investment \\
\hline Factor block & & GDP calculation & \\
\hline AVWF(iff,k) & Average wage with current weights & RGDP & Real GDP \\
\hline FDSC(i,iff,k) & Factor demand by sector & GDPVA(k) & Value added in market prices GDP \\
\hline FS(iff,k) & Factor supply & OBJECT & Value of objective function \\
\hline $\mathrm{FT}(\mathrm{k})$ & Factor tax & WALRAS & Walras law for system \\
\hline WF(iff,k) & Average factor price & WALRAS1(k) & Walras law for each country on balance \\
\hline WFDIST(i,iff,k) & Factor differential & & of trade \\
\hline YFCTR(iff,k) & Factor income & WALRAS2(k) & $\begin{array}{l}\text { Walras law for each country on saving } \\
\& \text { investment }\end{array}$ \\
\hline Migration block & & WALRAS3(i,k) & Adding up constraint for smq \\
\hline WGDFL(la,k,lb,l) & Wage differentials & & \\
\hline MIGL(la,k) & Labor migration flows (within category) & & \\
\hline MIGRU(la,k) & Labor migration flows (across category) & & \\
\hline
\end{tabular}


Table II: Country, Sectoral and Factor Classifications in the KIM-C GE M odel

Countries and regions

$\mathrm{K}(\mathrm{CTY} 1)$

Countries

Sectors and groupings

I,J

Sectors of production
NK

SK

RT

NK

SK

\author{
NORTH KOREA \\ SOUTH KOREA \\ REST OF THE WORLD \\ NORTH KOREA \\ SOUTH KOREA
}

RICE

OTHER GRAIN

OTHER AGRICULTRAL PRODUCTS

MINING

LIGHT MANUFACTURES

INTERMEDIATE GOODS

CAPITAL GOODS

CONSTRUCTION

PUBLIC ADMINISTRATION

MILITARY

SERVICES

$\operatorname{im}(\mathrm{i}, \mathrm{k})$
$\operatorname{imn}(\mathrm{i}, \mathrm{k})$
ie(i,k)
ien(i,k)
imi(i,k,cty1)
iei(i,k,cty1)
$\operatorname{ie} 1(\mathrm{i}, \mathrm{k})$
$\operatorname{ied}(\mathrm{i}, \mathrm{k})$
$\operatorname{ik}(\mathrm{I})$
$\operatorname{iag}(\mathrm{I})$
$\operatorname{iagn(I)}$
$\operatorname{iserv}(\mathrm{I})$

Factors and groupings

iff,f

Import sectors

Non-import sectors

Export sectors

Non-export sectors

Bilateral imports in base data

Bilateral exports in base data

Aggregate CET export sectors

Downward sloping export demand from rest of world

Capital and intermediate goods sectors (INTER, KGOODS)

Agricultural sectors (AGRFSH)

Non-agricultural sectors

Service sector (SCV)
Factors of production

SVC

Households and institutions

$\begin{array}{ll}\text { hh } & \text { Households } \\ \text { ins } & \text { Institutions }\end{array}$

$\begin{array}{ll}\text { CAPITAL } & \text { Capital stock } \\ \text { LLAND } & \text { Low-yield land } \\ \text { MLAND } & \text { Medium-yield land } \\ \text { HLAND } & \text { High-yield land } \\ \text { AGLAB } & \text { Rural agricultural labor } \\ \text { URBUNSK } & \text { Urban unskilled labor } \\ \text { URBSKLD } & \text { Urban skilled labor } \\ & \\ \text { HHALL } & \text { Single household category } \\ \text { LABR } & \text { Labor } \\ \text { ENT } & \text { Enterprises }\end{array}$


Table III: Parameters in the KIM-C GE M odel

\begin{tabular}{|c|c|}
\hline \multicolumn{2}{|l|}{ Basic model parameters } \\
\hline AGINVRAT(K) & Agregate investment rate \\
\hline CLES(i,hh,k) & Household consumption shares \\
\hline CTAX(i,k) & Consumption tax rates \\
\hline EB(i,cty1,cty2) & Exports, base data \\
\hline $\mathrm{EK} 0(\mathrm{i}, \mathrm{k})$ & Total sectoral exports, all destinations, base data \\
\hline ELASTICITY(ielas,i,k) & Sectoral elasticities \\
\hline $\operatorname{ENTR}(k)$ & Enterprise income tax rate \\
\hline FACTRES(iff,k) & Social security taxes \\
\hline FSO(iff,k) & Aggregate factor supply, base data \\
\hline FTAX0(k) & Factor tax rate \\
\hline GLES2(i,k) & Government non-military expenditure shares \\
\hline GOVRAT(k) & government expenditure rate \\
\hline $\operatorname{HHTR}(\mathrm{hh}, \mathrm{k})$ & Household income tax rate \\
\hline $\mathrm{IO}(\mathrm{i}, \mathrm{j}, \mathrm{k})$ & Input-output coefficients \\
\hline ITAX(i,k) & Indirect tax rates \\
\hline MPS(hh,k) & Savings propensities by households \\
\hline PVAB0(i,k) & Value added net of subsidies \\
\hline PWEB(i,cty1,cty2) & World price of exports, base data \\
\hline PWM0(i,cty1,cty2) & World market price of imports, base data \\
\hline PWTC(i,k) & Consumer price index weights (PQ) \\
\hline RATEX(i,k,cty1) & Export rationing rate \\
\hline RATM(i,k,cty1) & Import rationing rate \\
\hline $\mathrm{RHSH}(\mathrm{hh}, \mathrm{k})$ & Household shares of remittance income \\
\hline SECTRES(isec,i,k) & Sectoral quantities and prices \\
\hline SINTYH(hh,ins,k) & Household distribution of value added income \\
\hline SPREM(i,k) & Share of premium revenue to the government \\
\hline SSTR(iff,k) & Factor payment tax rate \\
\hline TARR(itarr,i,k,cty1) & Sectoral tariff rates \\
\hline TE(i,k) & Tax rates on exports \\
\hline THSH(hh,k) & Household transfer income shares \\
\hline $\mathrm{TM}(\mathrm{i}, \mathrm{k}, \mathrm{cty} 1)$ & Tariff rates on imports \\
\hline VATR(i,k) & Value added tax rate \\
\hline ZSHR(i,k) & Investment demand shares \\
\hline \multicolumn{2}{|c|}{ Production and trade function parameters } \\
\hline $\mathrm{AC}(\mathrm{i}, \mathrm{k})$ & Armington function shift parameter \\
\hline $\mathrm{AD} 2(\mathrm{i}, \mathrm{k})$ & CES production function shift parameter \\
\hline $\mathrm{AE}(\mathrm{i}, \mathrm{k})$ & CET export composition function shift parameter \\
\hline $\mathrm{AT}(\mathrm{i}, \mathrm{k})$ & CET function shift parameter \\
\hline ALPHA2(i,k) & Coefficient in CES production function \\
\hline GAMMA(i,k,cty1) & CET export composition function share parameters \\
\hline GAMMAK(i,k) & CET function share parameter \\
\hline RHOC(i,k) & Armington function exponent \\
\hline RHOE(i,k) & CET export composition function exponent \\
\hline RHOP(i,k) & CES production function exponent \\
\hline RHOT(i,k) & CET function exponent \\
\hline
\end{tabular}




\section{Table IV: Q uantity E quations}

(1) $\quad X(i, k)=A D 2(i, k) *(\operatorname{SUM}($ iff\$FDSCO(i,iff, k), ALPHA2(i,iff, k)*FDSC (i,iff,k)**(-RHOP(i,k))) )**(-1/RHOP(i,k));

(2) $\quad(1-f t(k)) * W F(i f f, k) * W F D I S T(i, i f f, k)=\operatorname{SCALE}(i, k) *(1-\operatorname{vatr}(i, k)) * p v a(i, k) * A D 2(i, k) *(\operatorname{SUM}(f \$ F D S C O(i, f, k), A L P H A 2(i, f, k) * F D S C(i, f, k)$ **(-RHOP(i,k))) $) * *((-1 /$ RHOP(i,k)) - 1)*ALPHA2(i,iff, k)*FDSC $(\mathrm{i}, \mathrm{iff}, \mathrm{k}) * *(-\mathrm{RHOP}(\mathrm{i}, \mathrm{k})-1)$;

(3) $\quad$ INT(i,k) $=\operatorname{SUM}(\mathrm{j}, \mathrm{IO}(\mathrm{i}, \mathrm{j}, \mathrm{k}) * \mathrm{X}(\mathrm{j}, \mathrm{k}))$;

\section{Model Specification}

In addition to eleven sectors for each country model, the model has seven factors of production (agriculture labor, unskilled urban labor, skilled urban labor, capital and three types of land), as identified in Table II. The output-supply and input-demand equations are shown in Table IV. Output is produced according to a CES function of the primary factors (equation 1), with intermediate inputs demanded in fixed proportions (equation 3). Producers are assumed to maximize profits, implying that each factor is demanded so that marginal product equals marginal cost (equation 2). In each economy, factors are not assumed to receive a uniform wage or "rental" (in the case of capital) across sectors; "factor market distortion" parameters (the WFDIST that appears in equation 2) are imposed fixing the ratio of the sectoral return to a factor relative to the economywide average return for that factor.

\section{Table V: Price Equations}

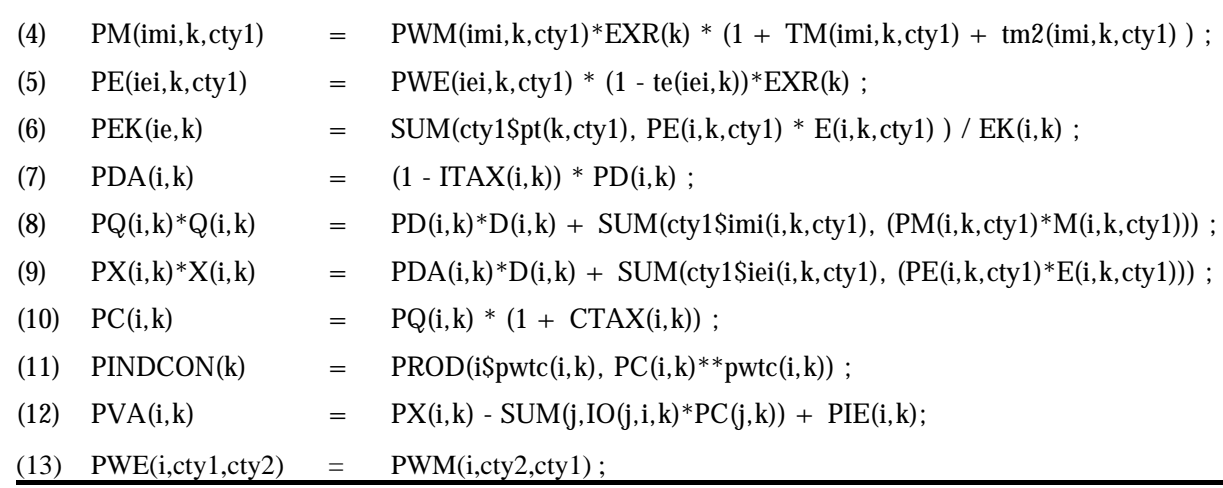

The price equations are shown in Table V. In equations 4 and 5, world prices are converted into domestic currency, including any tax or tariff components. Equation 13 guarantees cross-trade price consistency, so that the world price of country A's exports to country 
B are the same as the world price of country B's imports from country A. Equation 6 defines the aggregate export price as the weighted sum of the export price to each destination. Equation 7 calculates the domestic price, net of indirect tax. Equations 8 and 9 describe the prices for the composite commodities $Q$ and $X$. $Q$ represents the aggregation of sectoral imports $(M)$ and domestic goods supplied to the domestic market $(D)$. $X$ is total sectoral output, which is a CET aggregation of total supply to export markets $(E)$ and goods sold on the domestic market $(D)$. Equation 10 defines the consumption price of composite goods from the composite good price $(P Q)$ and consumption taxes $(t c)$. Equation 12 defines the sectoral price of value-added, or "net" price $(P V A)$, as the output price minus the unit cost of intermediate inputs (from the input-output coefficients).

In the KIM-CGE model, the aggregate consumer price index in each region is set exogenously (PINDCON in equation 11), defining the numeraire. The advantage of this choice is that solution wages and incomes are in real terms; moreover, since our Cobb-Douglas price index is consistent with the underlying Cobb-Douglas utility function, the changes in consumption levels generated by the model are exactly equal to the equivalent variation. The solution exchange rates in the sub-regions are also in real terms and can be seen as equilibrium price-level-deflated (PLD) exchange rates, using the country consumer price indices as deflators. The exchange rate for the rest of the world is fixed, thereby defining the international numeraire. 


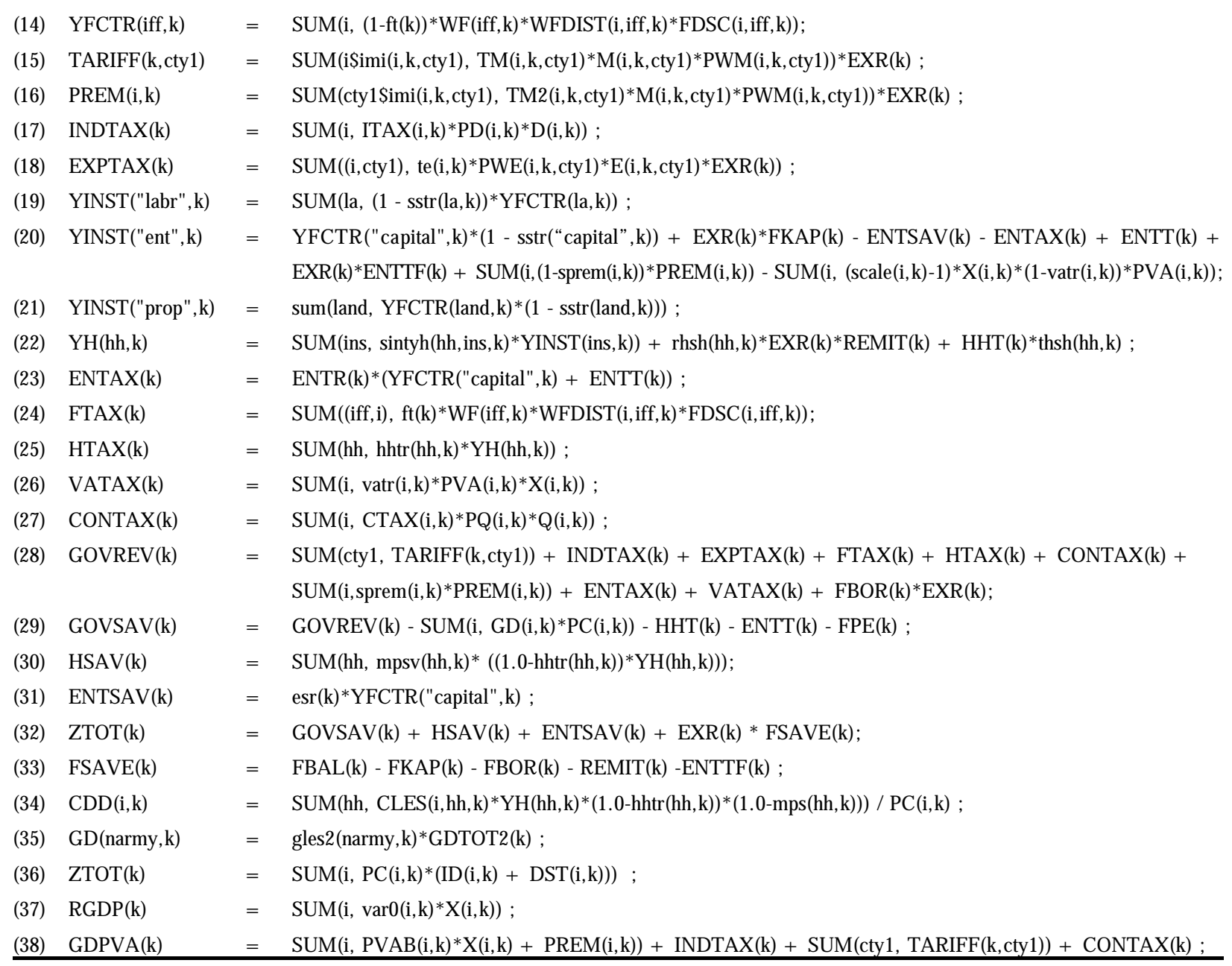

The circular flow of income from producers, through factor payments to households, government, and investors, and finally back to demand for goods in product markets is shown in the equations in Table VI. The country models incorporate official tariff revenue (TARIFF in equation 15), which flow to the government, and the tariff equivalent of non-tariff barriers (PREM in equation 16), which accrues as rents to the private sector. Each economy is modeled as having a number of domestic market distortions, including sectorally differentiated indirect, consumption, and value-added taxes as well as factor, household, and corporate income taxes (equations 17-18 and 23-27). The single household category in each economy has a CobbDouglas expenditure function (equation 34). Investment is set in equation 36. Aggregate real 
government consumption is set fixed in the model, while sectoral government consumption is set in equations 35. Equation 37 and 38 are definitions for GDP value-added and real GDP.

Table VII: Export Equations

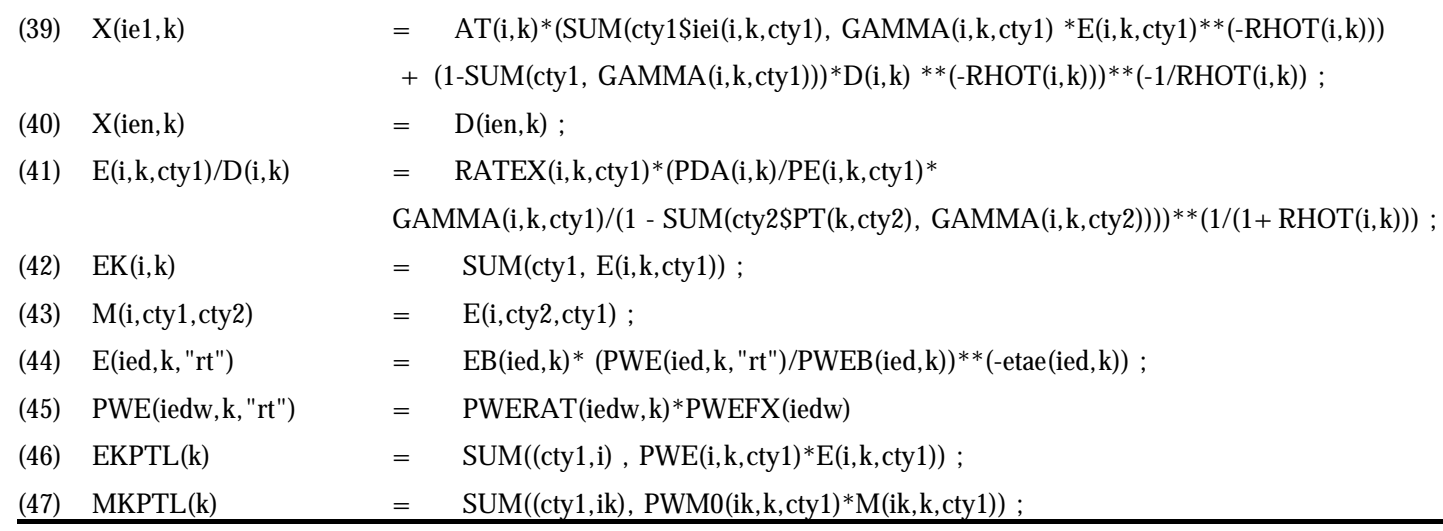

Export-related functions are shown in Table VII. Exports are supplied according to a CET function between domestic sales and total exports (equation 39), and allocation between export and domestic markets occurs in order to maximize revenue from total sales (equation 41). The rest of the world is modeled as a large supplier of imports to each country at fixed world prices. Rest of world demand for the North and South Korean exports is modeled as occurring at fixed world prices. The world prices for North and South Korea are assumed to be exogenous a typical small country assumption.

\section{Table VIII: CES Import Demand Equations}

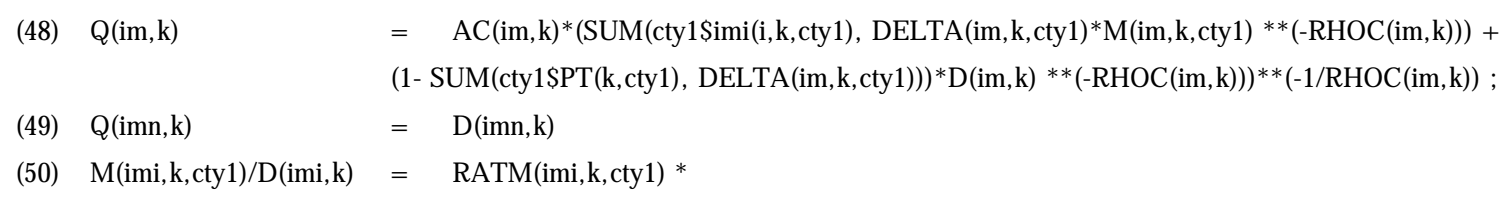

The specification of CES functions for imports is shown in Table VIII. We adopt the notation convention that when $k=c t y l$, we are describing the domestic component of composite demand (D). Imn indicates non-importing sectors, therefore equation 49 shows that for nonimporting sectors, the demand is equal to the domestic production. 
(51) $(\operatorname{AVWF}(\mid \mathrm{l}, \mathrm{k}) / \mathrm{EXR}(\mathrm{k}))=\operatorname{wgdfl}(\mathrm{la}, \mathrm{k}, \mathrm{la}, \mathrm{l}) *(\operatorname{AVWF}(\mathrm{la}, \mathrm{I}) / \mathrm{EXR}(\mathrm{I}))$;

(52) $\mathrm{FS}(\mathrm{la}, \mathrm{k})=\mathrm{FSO}(\mathrm{la}, \mathrm{k})+\mathrm{MIGL}(\mathrm{la}, \mathrm{k})+\mathrm{MIGRU}(\mathrm{la}, \mathrm{k})$;

(53) $\operatorname{SUM}(\mathrm{la}, \mathrm{MIGRU}(\mathrm{la}, \mathrm{k}))=0$;

Table IX outlines the labor and capital migration relations in the model (which are in the simulations reported in this paper). Cross-border capital and labor flows in this paper are determined by the per capita GDP differentials between North and South Korea. The 60 percent per capita income differential is used as the criteria to decide how much capital from South Korea and how many people from North Korea need to be moved in opposite direction across the border. Internal migration in each country maintains a specified ratio of average real wages between the rural and unskilled urban markets (the EXR terms become irrelevant). Domestic labor and capital supply in each country is then adjusted by the capital and labor movements (equation 52), while the other two equations insure that workers do not "disappear" or get "created" in the migration process.

\section{Table X: Market-C learing E quations}

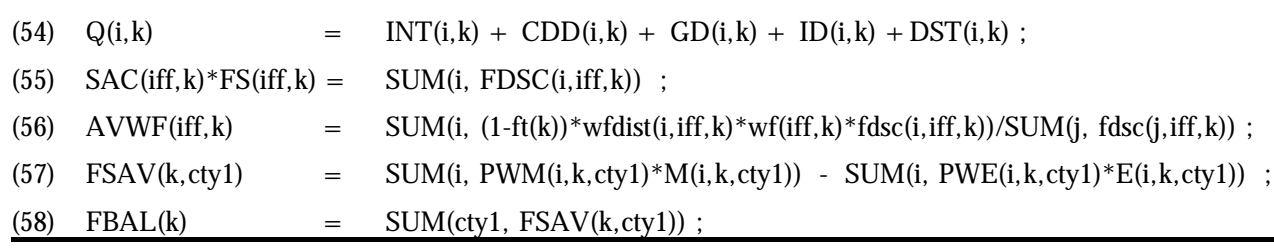

To complete the model, there are a number of additional "market-clearing" or equilibrium conditions that must be satisfied, as shown in Table X. Equation 54 is the material balance equation for each sector, requiring that total composite supply $(Q)$ equal the sum of composite demands. Equation 55 provides equilibrium in each factor market; Equation 57 is the balance condition in the foreign exchange market, requiring that import expenditures equal the sum of export earnings and net foreign capital inflows; equation 58 is the overall trade balance equation, summing up the bilateral trade balances. 


\section{Model Closure}

The KIM model permits a number of different "closure" choices that affect the macroeconomic relationships in the model. In all simulations reported in this paper except in the cases that we allow foreign capita inflow, we have assumed that the aggregate trade balance $(F B A L)$ is fixed for both countries, and that the exchange rate $(E X R)$ varies to achieve external balance in the customs union part of model. However, in the monetary union part of model, the exchange rate is fixed between the North and South. In addition, the balance of trade for the two countries are also fixed and unified. The separate North and South Korean trade balances can vary, though their sum is fixed. Government revenue is determined endogenously, given a variety of fixed tax rates, while government expenditure is fixed exogenously. Aggregate investment in each country is assumed to be a fixed share of GDP, and aggregate saving is assumed to adjust to equate total savings and investment. 
Appendix Table 1 (a): Import Rationing Ratios (Actual over Desired)

\begin{tabular}{|c|c|c|c|}
\hline Sector & North Korea & South Korea & Rest of the World \\
\hline RICE(NK) & 1.0 & 1.0 & 0.072 \\
\hline RICE(SK) & 1.0 & 1.0 & 1.0 \\
\hline OGRAIN(NK) & 1.0 & 1.0 & 0.162 \\
\hline OGRAIN(SK) & 1.0 & 1.0 & 1.0 \\
\hline AGOTH(NK) & 1.0 & 1.0 & 0.145 \\
\hline AGOTH(SK) & 0.223 & 1.0 & 1.0 \\
\hline MINING(NK) & 1.0 & 1.0 & 0.682 \\
\hline MINING(SK) & 0.037 & 1.0 & 1.0 \\
\hline LMANUF(NK) & 1.0 & 0.263 & 0.274 \\
\hline LMANUF(SK) & 0.05 & 1.0 & 1.0 \\
\hline INTERM(NK) & 1.0 & 0.105 & 0.480 \\
\hline INTERM(SK) & 0.447 & 1.0 & 1.0 \\
\hline KGOODS(NK) & 1.0 & 0.060 & 0.258 \\
\hline KGOODS(SK) & 1.0 & 1.0 & 1.0 \\
\hline CONSTR(NK) & 1.0 & 1.0 & 1.0 \\
\hline CONSTR(SK) & 1.0 & 1.0 & 1.0 \\
\hline PUBADM(NK) & 1.0 & 1.0 & 1.0 \\
\hline PUBADM(SK) & 1.0 & 1.0 & 1.0 \\
\hline ARMY(NK) & 1.0 & 1.0 & 1.0 \\
\hline ARMY(SK) & 1.0 & 1.0 & 1.0 \\
\hline $\mathrm{SVC}(\mathrm{NK})$ & 1.0 & 1.0 & 0.532 \\
\hline SVC(SK) & 1.0 & 1.0 & 1.0 \\
\hline
\end{tabular}

Note: Sectors with NK or SK in parentheses indicate the rates of import rationing imposed with respect to themselves and their respective foreign sectors. For example, the row of KGOODS(NK) shows that the rationing parameters imposed on the same sector in South Korea and the rest of the world are .060 and .258, respectively. If the rationing parameter is less than one, quantity restriction takes place. If the ration parameter is equal to one, there is no rationing. If the rationing parameter is greater than one, import quantity diversion takes place. The smaller the ratio, the larger the distortion. 
Appendix Table 1 (b): Export Rationing Ratios (Actual over Desired)

\begin{tabular}{|c|c|c|c|}
\hline Sector & North Korea & South Korea & Rest of the World \\
\hline RICE(NK) & 1.0 & 1.0 & 1.0 \\
\hline RICE(SK) & 1.0 & 1.0 & 1.0 \\
\hline OGRAIN(NK) & 1.0 & 1.0 & 1.0 \\
\hline OGRAIN(SK) & 1.0 & 1.0 & 1.0 \\
\hline AGOTH(NK) & 1.0 & 0.223 & 0.996 \\
\hline AGOTH(SK) & 1.0 & 1.0 & 1.0 \\
\hline MINING(NK) & 1.0 & 0.037 & 0.264 \\
\hline MINING(SK) & 1.0 & 1.0 & 1.0 \\
\hline LMANUF(NK) & 1.0 & 0.050 & 0.140 \\
\hline LMANUF(SK) & 0.263 & 1.0 & 1.0 \\
\hline INTERM(NK) & 1.0 & 0.447 & 0.391 \\
\hline INTERM(SK) & 0.105 & 1.0 & 0.984 \\
\hline KGOODS(NK) & 1.0 & 1.0 & 0.999 \\
\hline KGOODS(SK) & 0.06 & 1.0 & 0.998 \\
\hline CONSTR(NK) & 1.0 & 1.0 & 1.0 \\
\hline CONSTR(SK) & 1.0 & 1.0 & 1.0 \\
\hline PUBADM(NK) & 1.0 & 1.0 & 1.0 \\
\hline PUBADM(SK) & 1.0 & 1.0 & 1.0 \\
\hline ARMY(NK) & 1.0 & 1.0 & 1.0 \\
\hline ARMY(SK) & 1.0 & 1.0 & 1.0 \\
\hline $\mathrm{SVC}(\mathrm{NK})$ & 1.0 & 1.0 & 0.590 \\
\hline SVC(SK) & 1.0 & 1.0 & 1.0 \\
\hline
\end{tabular}

Note: Sectors with NK or SK in parentheses indicate the rates of export rationing imposed with respect to themselves and their respective foreign sectors. For example, the row of INTERM(NK) shows that the rationing parameters imposed on the same sector in South Korea and the rest of the world are .447 and 0.391 respectively. If the rationing parameter is less than one, quantity restriction takes place. If the ration parameter is equal to one, there is no rationing. If the rationing parameter is greater than one, export quantity diversion takes place.

\section{Appendix Table 2: Elasticities}




\begin{tabular}{|c|c|c|c|c|}
\hline Sector & $\begin{array}{c}\text { SK } \\
\text { Import } \\
\text { Substitution }\end{array}$ & $\begin{array}{c}\text { SK } \\
\text { Export } \\
\text { Transformation }\end{array}$ & $\begin{array}{c}\text { ROW } \\
\text { Import } \\
\text { Substitution }\end{array}$ & $\begin{array}{c}\text { ROW } \\
\text { Export } \\
\text { Transformation }\end{array}$ \\
\hline RICE(NK) & 3.0 & 2.0 & 3.0 & 2.0 \\
\hline OGRAIN(NK) & 2.0 & 3.0 & 2.0 & 3.0 \\
\hline AGOTH(NK) & 2.0 & 1.5 & 2.0 & 1.5 \\
\hline MINING(NK) & 1.5 & 1.2 & 1.5 & 1.2 \\
\hline LMANUF(NK) & 1.5 & 4.0 & 1.5 & 4.0 \\
\hline INTERM(NK) & 2.0 & 1.5 & 2.0 & 1.5 \\
\hline KGOODS(NK) & 1.5 & 4.0 & 1.5 & 4.0 \\
\hline CONSTR(NK) & 2.0 & 3.0 & 2.0 & 3.0 \\
\hline PUBADM(NK) & 2.0 & 4.0 & 2.0 & 4.0 \\
\hline ARMY(NK) & 2.0 & 4.0 & 2.0 & 4.0 \\
\hline SVC(NK) & 2.0 & 2.0 & 2.0 & 2.0 \\
\hline Sector & $\begin{array}{c}\text { NK } \\
\text { Import } \\
\text { Substitution }\end{array}$ & $\begin{array}{c}\text { NK } \\
\text { Export } \\
\text { Transformation }\end{array}$ & $\begin{array}{c}\text { ROW } \\
\text { Import } \\
\text { Substitution }\end{array}$ & $\begin{array}{c}\text { ROW } \\
\text { Export } \\
\text { Transformation }\end{array}$ \\
\hline RICE(SK) & 2.0 & 2.0 & 2.0 & 2.0 \\
\hline OGRAIN(SK) & 2.0 & 2.0 & 2.0 & 2.0 \\
\hline AGOTH(SK) & 2.0 & 2.0 & 2.0 & 2.0 \\
\hline MINING(SK) & 2.0 & 2.0 & 2.0 & 2.0 \\
\hline LMANUF(SK) & 2.0 & 3.0 & 2.0 & 3.0 \\
\hline INTERM(SK) & 2.0 & 2.0 & 2.0 & 2.0 \\
\hline KGOODS(SK) & 2.0 & 4.0 & 2.0 & 4.0 \\
\hline CONSTR(SK) & 2.0 & 2.0 & 2.0 & 2.0 \\
\hline PUBADM(SK) & 2.0 & 2.0 & 2.0 & 2.0 \\
\hline ARMY(SK) & 2.0 & 2.0 & 2.0 & 2.0 \\
\hline SVC(SK) & 2.0 & 2.0 & 2.0 & 2.0 \\
\hline
\end{tabular}

Note: Sectors with NK and SK in parentheses indicate the substitution and transformation elasticities used in these sectors against their respective partners. For example, the row of SVC(NK) shows that North Korean service sector's elasticities of import substitution and export transformation with respect to goods from the same sector of South Korea and the rest of the world are 2.

\section{References}


Akerlof, George A., Andrew K. Rose, Janet L. Yellen, and Helen Hessenius. (1991). "East Germany in from the Cold," Brookings Papers on Economic Activity 1 1-105.

Bae, Jin-Young. 1996. "The Fiscal Burden of Korean Reunification and Its Impact on South Korea’s Macroeconomic Stability,” Joint U.S.-Korea Academic Studies, 6, 185-202.

Barro, Robert J. and Xavier Sala-i-Martin. 1992. "Convergence," Journal of Political Economy, 100:2 223-51.

Barro, Robert J. and Xavier Sala-i-Martin. 1995. Economic Growth. New York: McGraw-Hill.

Boltho, Andrea, Wendy Carlin, and Pasquale Scaramozzino. 1997. "Will East Germany Become the New Mezzogiorno?," Journal of Comparative Economics, 24 241-64.

Brooke, Anthony, Kendrick, David, and Alexander Meeraus. (1992) GAMS: A User's Guide. Massachusetts, Boyd \& Fraser Publishing Company.

Burda, Michael and Michael Funke. 1993. "Eastern Germany: Can’t We Be More Optimistic?” CEPR Discussion Paper No. 893, London: Centre for Economic Policy Research.

Carlin, Wendy and Colin Meyer. (1994). "The Treuhandanstalt," in Olivier Blanchard, Kenneth Froot, and Jeffrey Sachs, editors, The Transition in Eastern Europe vol. 2, Chicago: University of Chicago Press.

Coe, David T., Elhanan Helpman, and Alexander Hoffmaister. (1996). "North-South R\&D Spillovers," Economic Journal 107:440, 134-49.

Deaton, Angus and Muellbauer, John. (1980). Economics and Consumer Behavior. Cambridge: Cambridge University Press.

Dervis, Kemal, de Melo, Jaime, and Sherman Robinson. (1982). General Equilibrium Models for Development Policy, New York: Cambridge University Press.

Devarajan, Shanta, Lewis, Jeffrey D., and Sherman Robinson. (1994). Getting the Model Right: The General Equilibrium Approach to Adjustment Policy. Forthcoming.

Dornbusch, Rudiger and Holger C. Wolf. (1994). "East German Economic Reconstruction," in Olivier Jean Blanchard, Kenneth A. Froot, and Jeffrey D. Sachs eds., The Transition in Eastern Europe, vol. 1, Chicago: University of Chicago Press.

Dyck, I.J. Alexander. (1997). "Privatization in Eastern Germany: Management Selection and Economic Transmission," American Economic Review, 87:4 565-97.

Flassbeck, Heiner and Gustav Horn. (1996). German Unification: An Example for Korea?, 
Brookfield: Ashgate Publishing Company.

Food and Agriculture Organisation. 1997. "Special Report: FAO/WFP Crop and Food Supply Assessment Mission to the Democratic People’s Republic of Korea," 25 November 1997.

Golan, Amos., Judge, George., and Robinson, Sherman. (1994). Recovering Information from Incomplete or Partial Multisectoral Economic Data. The Review of Economics and Statistics, LXXVI(3), 541-549.

Herz, Bernhard and Werner Roger. 1995. "Economic Growth and Convergence in Germany," Weltwirtschaftliches Archiv, 131:1

Hughes Hallett, Andrew J. and Yue Ma. 1997. "East Germany, West Germany, and their Mezzogiorno Problem: an Empirical Investigation," CEPR Discussion Paper No. 623, Centre for Economic Policy Research: London (February).

Hughes Hallett, A., Y. Ma, and J. Melitz. (1996). "Unification and the Policy Predicament in Germany," Economic Modeling 13 519-44.

Hwang, Eui-Gak. (1993). The Korean Economies, Oxford: Clarendon Press.

Keller, Wolfgang. 1997. "From Socialist Showcase to Mezzogiorno? Lessons on the Role of Technical Change from East Germany's Post-World War II Growth Performance," University of Wisconsin: Madison, processed (May).

Korean Development Bank. (1994). North Korea's Economy and Industry. KDB Economic and Industrial Focus, Seoul, (September).

Kwon, Goohoon. 1997. "Experiences with Monetary Integration and Lessons for Korean Unification,” Washington: International Monetary Fund, processed.

Lee, Young Sun. (1994). Economic Integration of the Korean Peninsula: A Scenario Approach to the Cost of Unification, in Sung Yeung Kwack ed. The Korean Economy at a Crossroad, Westport, CT: Praeger.

Lee, Y.S. (1995). Is Korean Unification Possible? Korea Focus, 3(3), 5-21.

Lipschitz, Leslie and Donogh McDonald. (1990). "German Unification: Economic Issues," Occasional Paper 75, Washington: International Monetary Fund.

Noland, Marcus. (1996). The North Korean Economy. Joint U.S.-Korea Academic Studies, 6, 127-178.

Noland, Marcus. (1997). "German Lessons for Korea: The Economics of Unification," in C. Fred 
Bergsten and Il SaKong editors, The Korea - United States Economic Relationship, Washington: Institute for International Economics.

Noland, Marcus. (1998). "Introduction," in Marcus Noland editor, Economic Integration of the Korean Peninsula, Washington: Institute for International Economics.

Noland, Marcus, Robinson, Sherman, and LiGang Liu. (1998). "The Costs and Benefits of Korean Unification,” Asian Survey, Vol. XXXVIII No. 8 (August) 801-814.

Noland, Marcus, Sherman Robinson, and LiGang Liu. 1999. “The Economics of Korean Unification," Journal of Policy Reform, forthcoming.

Noland, Marcus., Robinson, Sherman., and Scatasta, Monica. (1997). "Modeling North Korean Economic Reform," Journal of Asian Economics, 8:1 15-38.

Park, Jin. 1997. “The Economic Impacts of Migration After Unification,” Seoul: Korea Development Institute, processed.

Pyatt, G., \& Round, J.I. (1985). Social Accounting Matrices: A Basis for Planning. Washington, D.C.: The World Bank.

Rummel, Ole J. 1997. "Why East Germany Failed to Become an Economic Tiger: Sobering Convergence Lessons from German Unification," Economic Policy in Transition Economies, Vol. 7 No. 3.

Schalk, Hans J. and Gerhard Untiedt. 1996. "Technologie im neoklassichen Wachstumsmodell: Effekte auf Wachstum und Konvergenz," Jahrbücher für Nationalokönomie und Statistik, 215:5 562-85.

Sinn, Gerlinde \& Sinn, Hans-Werner. (1992). Jumpstart. Cambridge: MIT Press.

Sinn, Hans-Werner. 1995. "Staggering Along: wages policy and investment support in East Germany," Economics of Transition. 3:4 403-26.

Stone, R., (1986). Nobel Memorial Lectures 1984: The Accounts of Society. Journal of Applied Econometrics, 1, 5-28.

Thimann, Christian and M.H. Breitner. (1995). "Eastern Germany and the Conflict between Wage Adjustment, Investment, and Employment: A Numerical Analysis," Weltwirtschaftliches Archiv 131 446-69.

United Nations Development Program. 1998. “Thematic Roundtable on Agricultural Recovery 
and Environmental Protection in the DPR Korea," Geneva, 28-29 May, processed.

Williamson, John. 1994. Estimating Equilibrum Exchange Rates. Washington: Institute for International Economics.

Wolf, Holger. (1998). "Korean Unification: Lessons From Germany,” in Marcus Noland editor, Economic Integration of the Korean Peninsula, Washington: Institute for International Economics.

World Bank. (1985). China: Economic Structure and International Perspective, Washington: International Bank for Reconstruction and Development.

Yeon, Ha-Cheong. 1994. "Economic Consequences of German Unification and Its Policy Implications for Korea," In Perspectives of Global Responsibility, New York: Inter Action Council.

Young, Soogil, Chang-Jae Lee, and Hyoungsoo Zang. (1998). "Preparing for Economic Integration of Two Koreas: Policy Challenges to South Korea," in Marcus Noland editor, Economic Integration of the Korean Peninsula, Washington: Institute for International Economics. 